Portland State University

PDXScholar

3-14-2017

\title{
Not a Dirty Word: Encouraging Feminist Activism through Design and Social Practices
}

Gabriella L. McKenzie

Portland State University

Follow this and additional works at: https://pdxscholar.library.pdx.edu/honorstheses

Let us know how access to this document benefits you.

\section{Recommended Citation}

McKenzie, Gabriella L., "Not a Dirty Word: Encouraging Feminist Activism through Design and Social Practices" (2017). University Honors Theses. Paper 391.

https://doi.org/10.15760/honors.387

This Thesis is brought to you for free and open access. It has been accepted for inclusion in University Honors Theses by an authorized administrator of PDXScholar. Please contact us if we can make this document more accessible: pdxscholar@pdx.edu. 
Not a Dirty Word:

Encouraging Feminist Activism through Design and Social Practices

by

Gabriella McKenzie

An undergraduate honors thesis submitted in partial fulfillment of the requirements for the degree of

Bachelor of Arts

in

University Honors

$\&$

Graphic Design

Thesis Adviser

Lis Charman

Portland State University 
$\mathrm{F} @ \# *$ !\$

1 Not a Dirty Word:

Encouraging Feminist

Activism through

Design and Social Practices

2 Mood Boards

3 Insights

4 Sketches

6 Final Images

7 Rationale 


\section{Not a Dirty Word:}

\section{Encouraging Feminist Activism through Design and Social Practices}

Gabi McKenzie

Winter 2017

Many young people identify with the statement

"I'm not a feminist, but..." (Buschman, Lenart, 2003). According to a survey of college-aged individuals, many of them identified with a feminist viewpoint; however, these individuals reject the label of feminist as well as the group mentality within feminist activism (Buschman, Lenart, 2003). How does one encourage young people that "feminist" isn't a negative label and that feminism is worthwhile? In my thesis I will attempt to answer this question and start to solve this problem through the use of design principles, printed matter, and factual information on feminism and young people. In this paper I will look into why young people disassociate themselves from feminism, give case study examples on successful design campaigns (involved in activism and otherwise), discuss methods for my thesis, address possible faults in this approach, present a strategy deck with an accompanying moodboard outlining tonal and visual approaches, images of my final project, and a rationale explaining decisions made during this process.

\section{Background}

When it comes to the feminist movement, young people feel disconnected for multiple reasons: they feel as if the work has already been done by generations past, the label of "feminist" has been molded to mean something negative or radical, or that nothing bad regarding gender equality has ever happened to them: therefore, it must not exist. Post feminists - or those who believe that "the war has already been won" - don't identify as feminists and have a weak desire to join a group collective which fights for women's equality (Buschman, Lenart, 2003). According to Rebecca Walker,

'Young women are struggling with the feminist label, not only, as some prominent Second Wavers have asserted, because we lack a knowledge of women's history and have been alienated by the media's generally horrific characterization offeminists.... Young women coming of age today wrestle with the term because we have a very different vantage point on the world than that of our foremothers.

Although Walker specifically mentions women here, not only are young people unaware of previous struggles or fights for equality, but many young people don't feel unequal or witness inequality in today's society. (Guy Sheftall, 2002). However, just because an individual isn't personally affected doesn't mean that inequality 
isn't happening: in Bushman and Lenart's 2003 survey, they found that women who had gone through negative experiences such as sexual assault, harassment, discrimination, verbal abuse, physical abuse, or had ever been made to feel stupid, inferior, or as less-than based on their gender were more likely to label themselves as a "feminist". This is where the disconnect lies, between those who have been through negative experiences and those who haven't. I will attempt to convince those who are unaware of negative experiences regarding gender equality that it does exist, that those who came before us fought so that we could have lives without discrimination, and that there is still work to be done through encouraging self-branding and conversation amongst peers.

\section{Case Studies}

As seen in Jen Ambrust's series "Card Carrying Feminist," a piece of cool and well designed printed matter can act as a social media campaign that relies on its participants as the method of travel fig.1,2,3. This series is an important reference point because it is a simple piece of design that has connected to so many. It was successful for two reasons. First being that it is a tangible and a heavy weighted piece of ephemeral paper that one can save and collect; the feeling of receiving a card like this in the mail and then displaying it on your desk, in your wallet, or adding it to your wall, is a feeling of excitement and preciousness. The second successful component of this piece is that it had a social campaign attached to it. Involving the audience directly and adding a hashtag let the audience brand themselves and present them- selves as part of this group.

In Civilization's "Death over Dinner" campaign, they created a website to encourage families and loved ones to talk about how they wanted to die either in old age or due to illness or accident. This project serves as a toolkit to encourage change in individuals lives through talking as well as encouraging change in the United States' hospital system. They encouraged this discussion by creating a website that acts as a blueprint, guiding the conversation through questionnaires, beautifully shot tablescapes, and an uplifting tone despite the heavy topic fig. 4, 5, 6. A look into Civilization's choices will inform my thesis by providing examples on how to brand a system that is focusing on a heavy topic while still remaining light and beautiful as well as sensitive to a difficult subject matter.

\section{Methods}

My thesis takes the shape of a branded box. It contains small self-branding memorabilia included along the likes of stickers, a feminist identification card, pins, prints, a feminist manifesto, feminist patches, a notebook, and a book on feminist changemakers that challenges my reader to go make their own change. This ensemble of material will act as a kit for a "new" feminist to be able to brand themselves to their friends, family, social media following, peers, as well as to help them inform themselves about the history of feminism and their next steps as a proud feminist.

I want this series of pieces to appear official in tone but still remain fun. To accomplish this I will reference mid century forms and office stationary. To make it appeal to my audience I will 
be modernizing these ideas by using juxtaposing informal language, type that references this time period while still feeling modern mixed with some loose hand lettering, and by using a bold color palette $\mathrm{fig}^{\mathrm{fi} 7-21}$.

\section{Possible Faults}

A possible area where my thesis may fall short is within intersectionality and race. I am a 21 year old white female with quite a privileged upbringing, connecting with an audience who I am not may prove to be difficult or read as false.

The audience that $I$ am attempting to appeal to are college aged individuals, primarily female. A constant struggle within design is toeing the edge between something that is "trendy" and current, and something that is "white 20-something hipster" in aesthetic. To attempt to combat this I will try to keep my official tone strong without feeling expensive, rather being well made and high craft but not excessive. Another area that will go unresolved is that this kit will not be able to live in the real world, I will only be making copies for me and for the honors college, not making it at a mass produced level. For this reason I will not be able to see if it is ultimately successful in achieving my goals. Despite these possible holes in my thesis, it will attempt to solve the problem of young people not being interested in feminism through a design campaign which hints that gender inequality does exist and try to inform my audience so that they no longer align with post-feminist thought.
I will try to convince them that those who came before us fought so that we could have lives without discrimination by implementing historic cases and stories. I will attempt to get across that there is still work to be done by inciting action, inspiration, and need for an active feminist young person. 


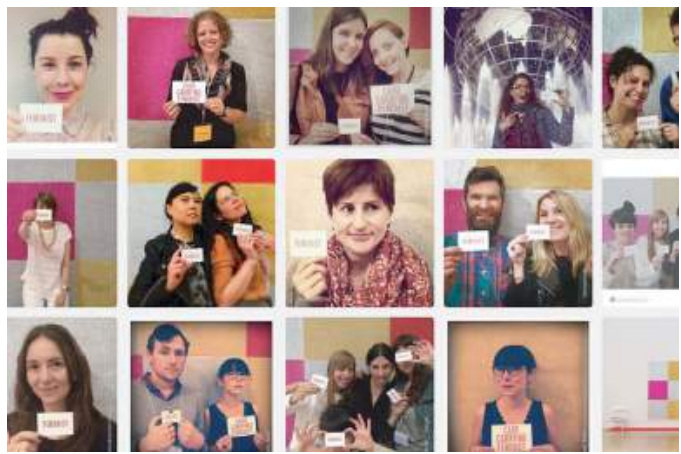

fig. 1

\section{FEMINIST}

fig. 2

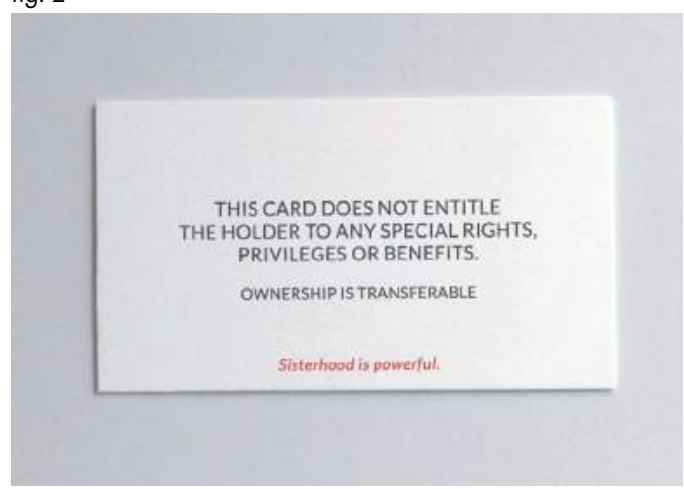

fig. 3

Card Carrying Feminist Ien Ambrust

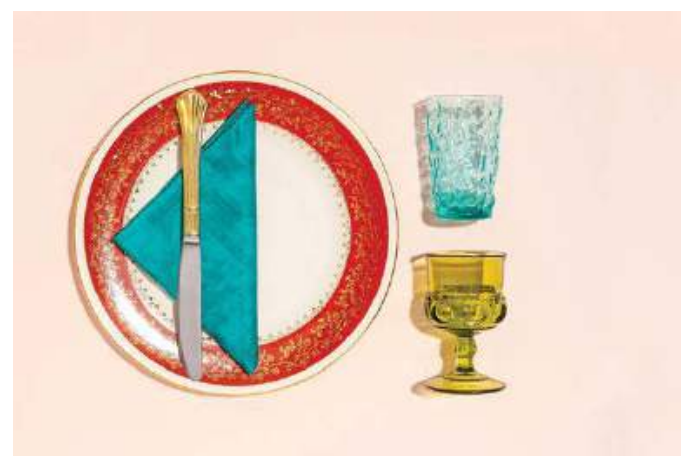

fig. 4

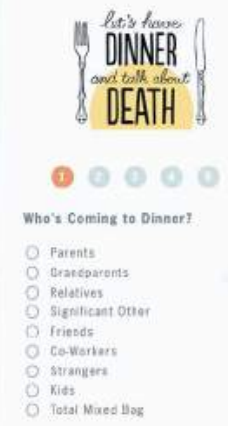

fig. 5
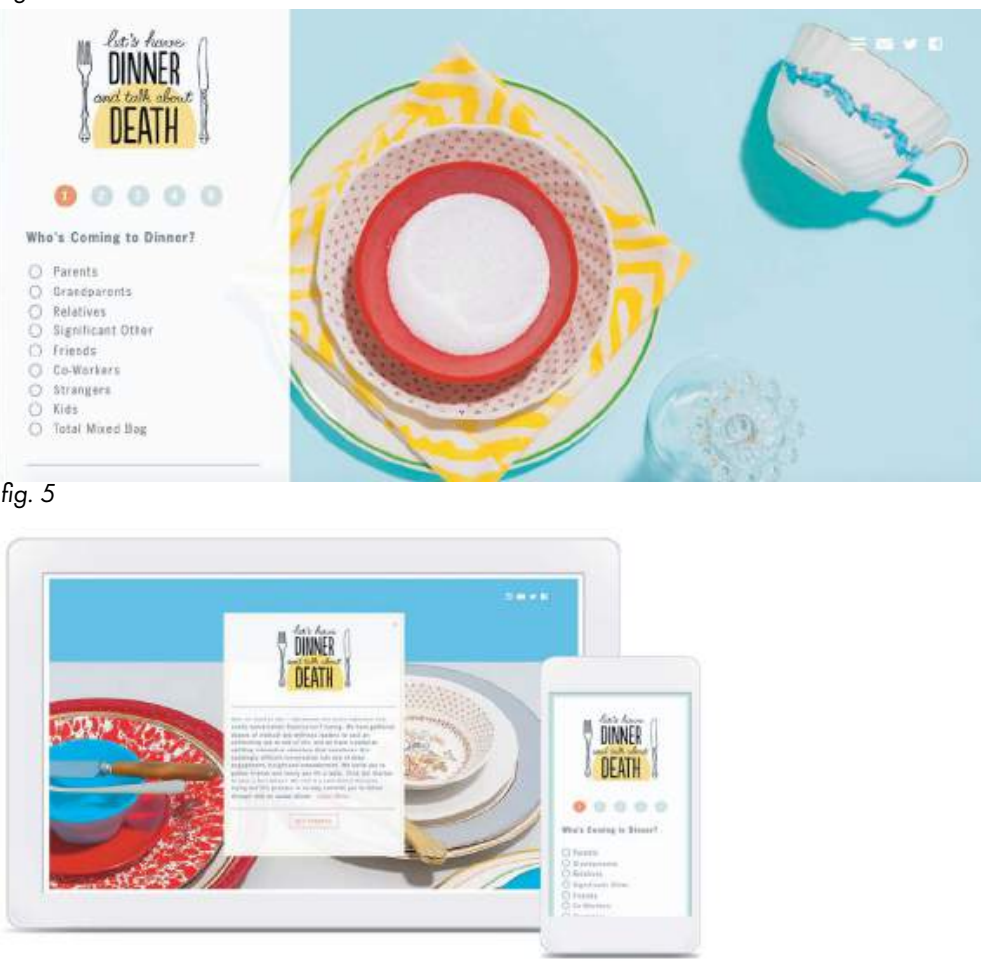

fig. 6

Death Over Dinner

Civilization 


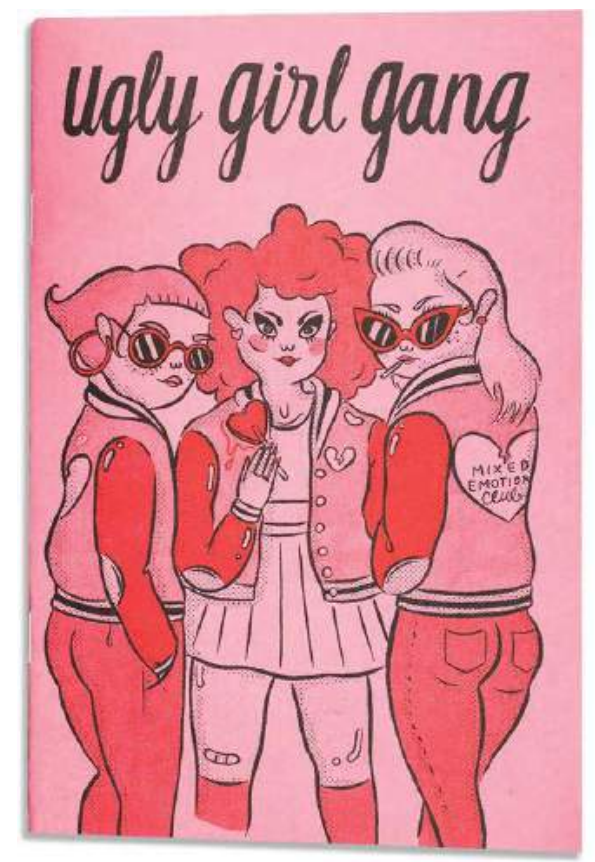

fig. 7

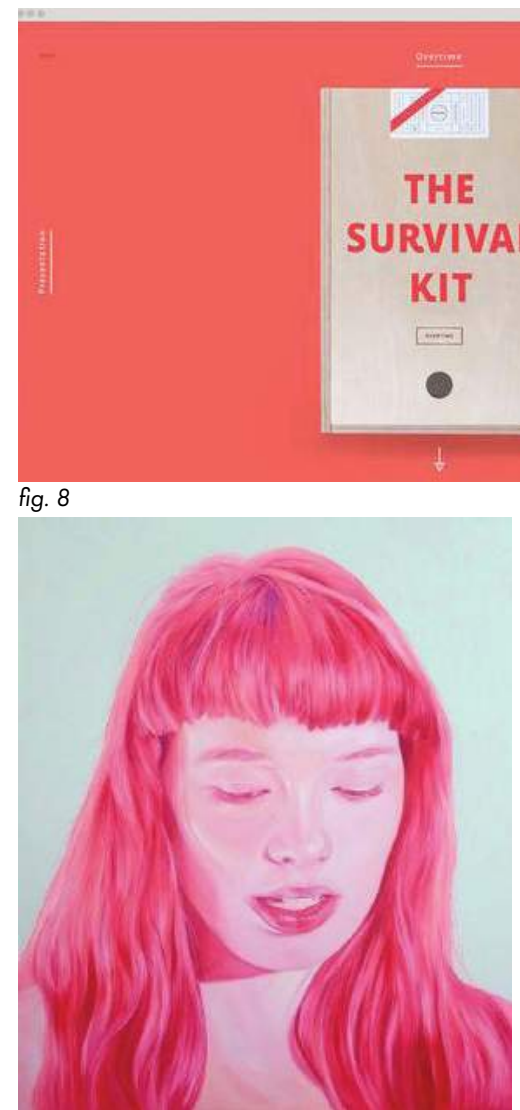

fig. 9

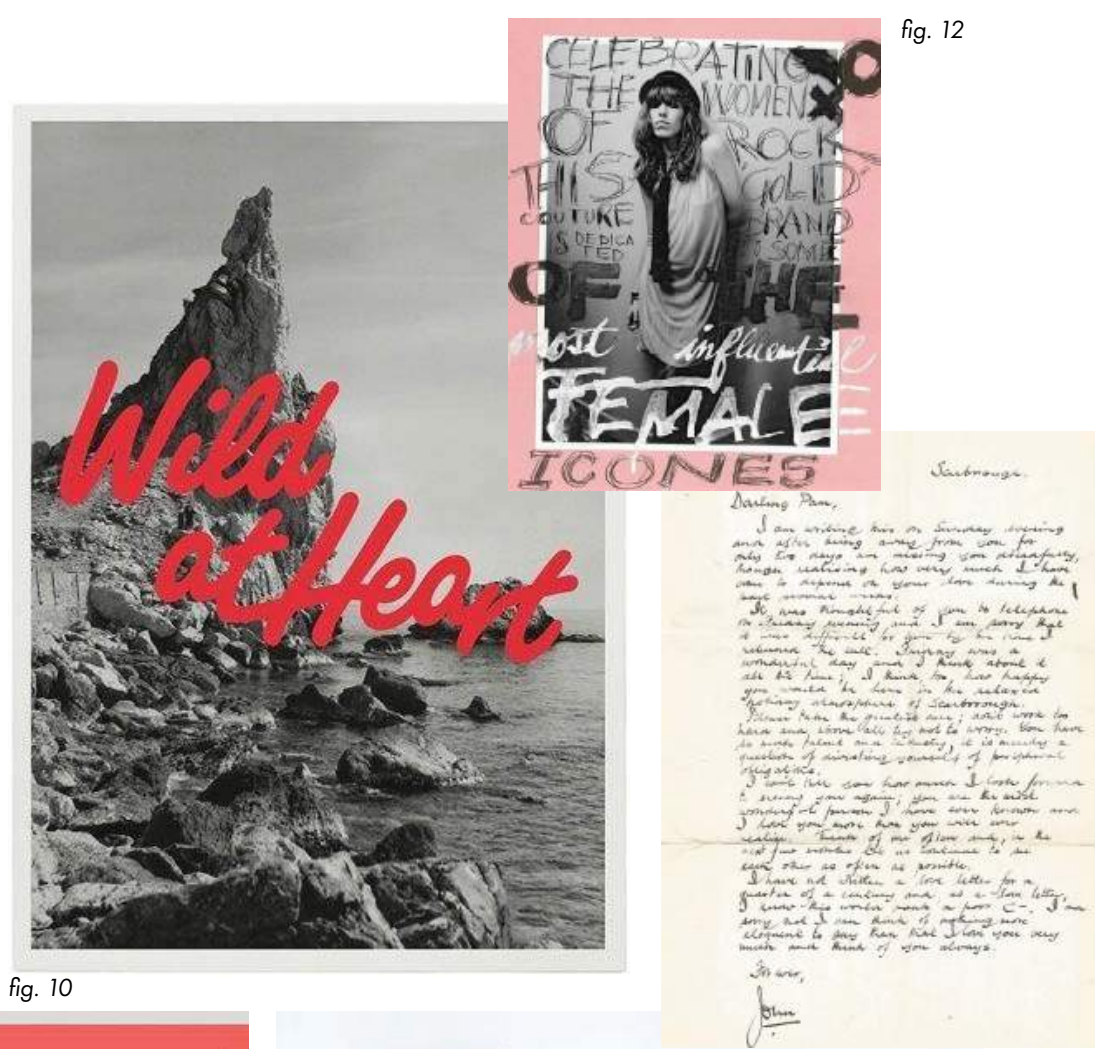

fig. 13

\section{Empowerment}

I want the tone to be unapologetically female and feminine without going completely girlish or total pink. I want it to feel like my audience owns this, that it is strong and expressive and legitimate. This concept mixes solid compositions with more expressive textures. It is monochromatic, bold, and a little bit precious in its touch-feel (heavy paper weight, feelable marks). Color I'm leaning towards is a bright orange-red.

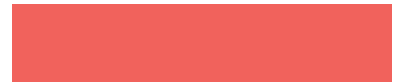


MOODBOARD Three: Branding + Packaging
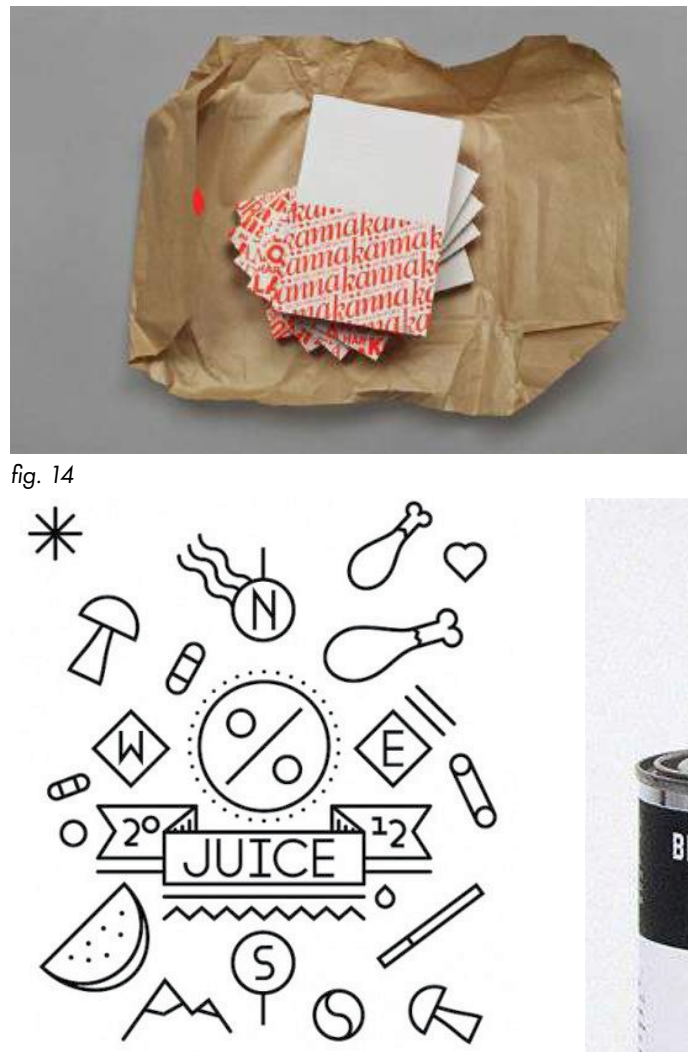

fig. 15
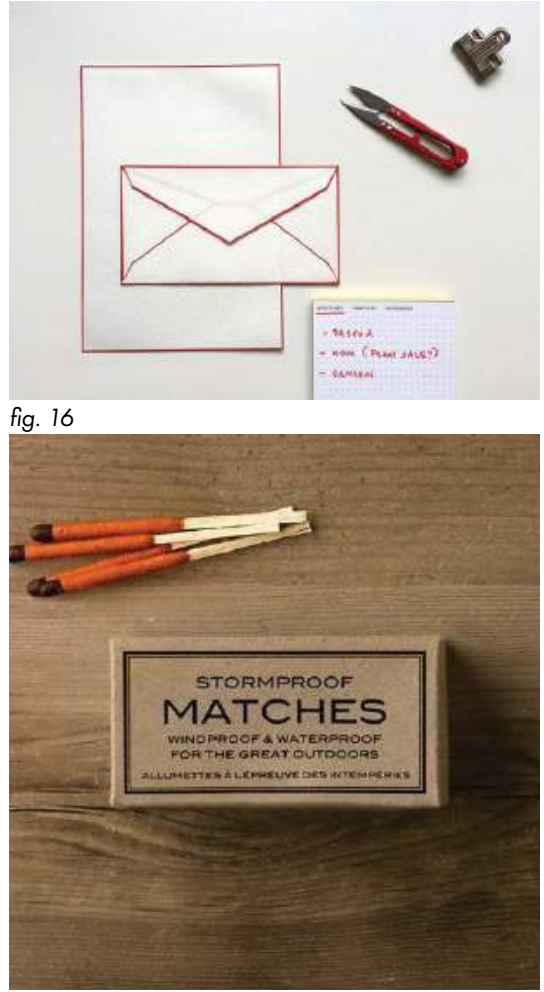

fig. 17

fig. 19

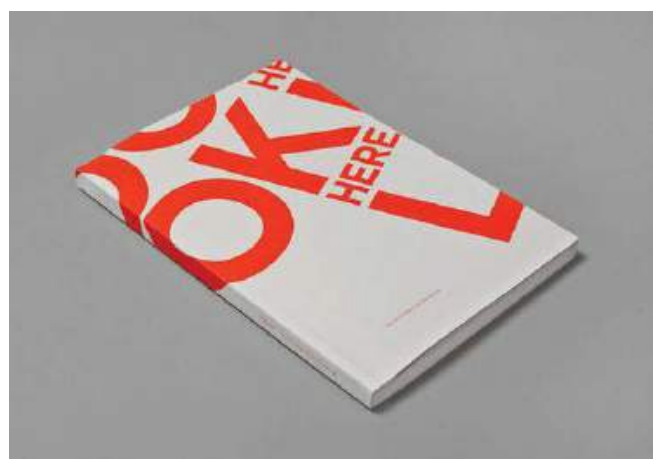

fig. 18

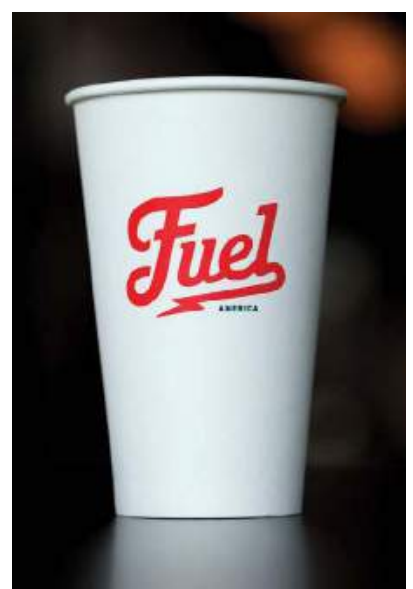

fig. 20

PAULE KA

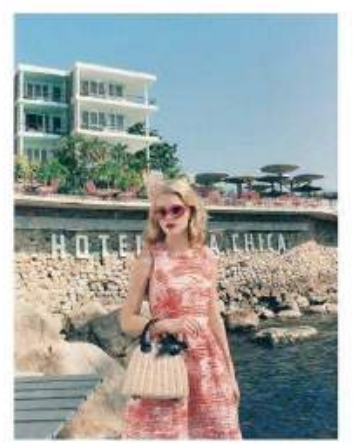

fig. 21

\section{Mid Century Legitimacy}

Here are some examples of branding sets. Fig. 19 especially reminds me of mid century packaging, simplistic and modern but it still has some complicated touches that feel handmade. For my thesis I want to reference stationary and really dig into details for every piece. 


\section{Strategy Deck}

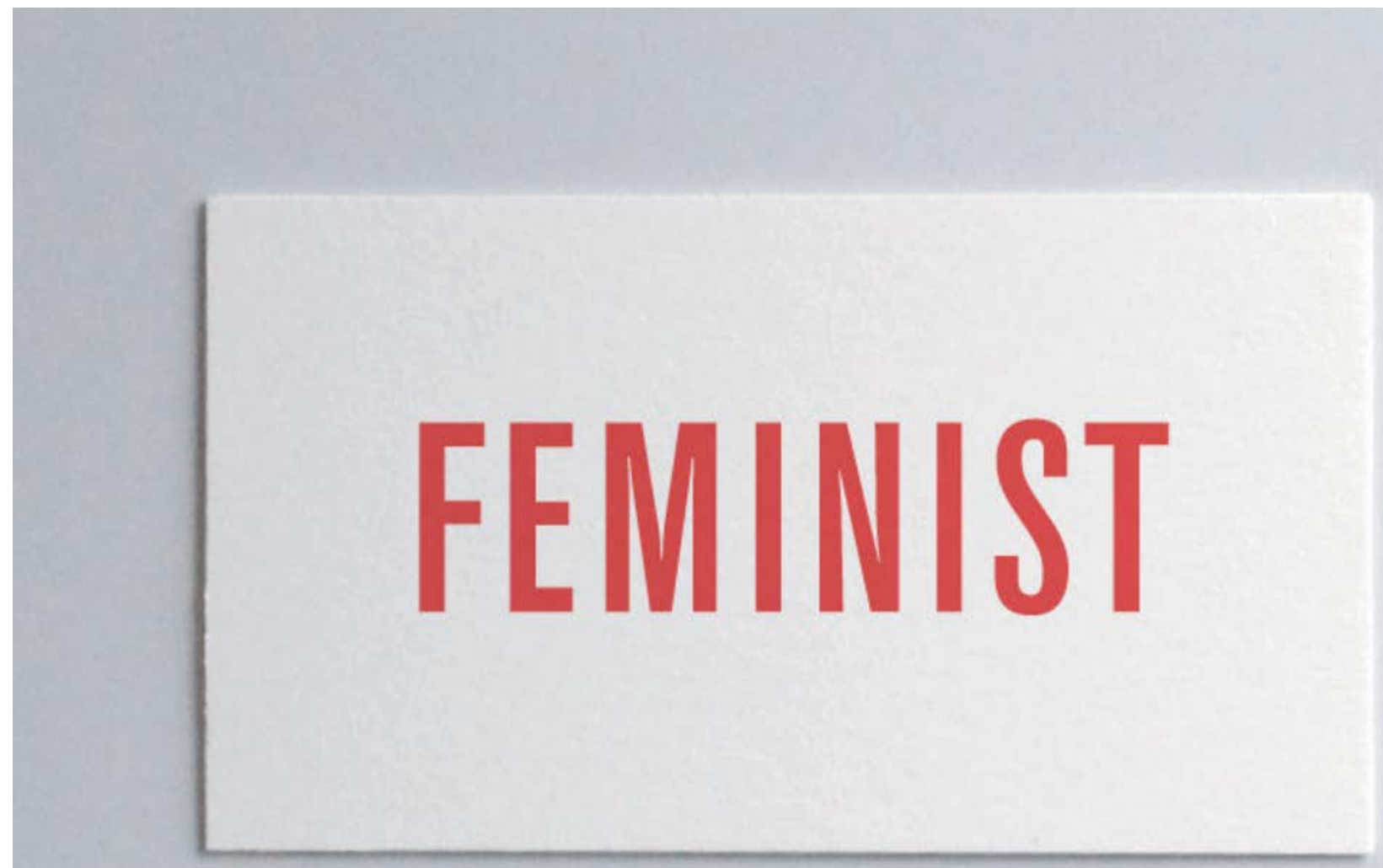

fig. 2

\section{Names + Theme /Programming}

NOT A DIRTY WORD

On owning the label.

F\#@!?*\$t

\section{Organization /Audience}

Ages 16-25. Young adults, students, women. Those who wish to make a life change in encouraging activism, becoming a feminist, or in expressing their support. Also for individuals who already identify as feminist and believe that their friend could recieve this guide to help make a change.

\section{Insights}

Many young people do not identify with feminism for the following reasons: - don't want to accept the label because it $h$ as become something negative/extremist - think that the "war has already been won" - have not experienced negative experienc$\mathrm{es}$, therefore it must not happen to others/really be that big of an issue.

\section{Big Idea/Concepts}

Creating a system so that individuals can brand themselves, figure out where they fall within feminism, and plan where they are going to go next with their new ideas.

\section{Verbal Voice}

Unapologetic, casual, empowering, friendly.

\section{Visual Voice}




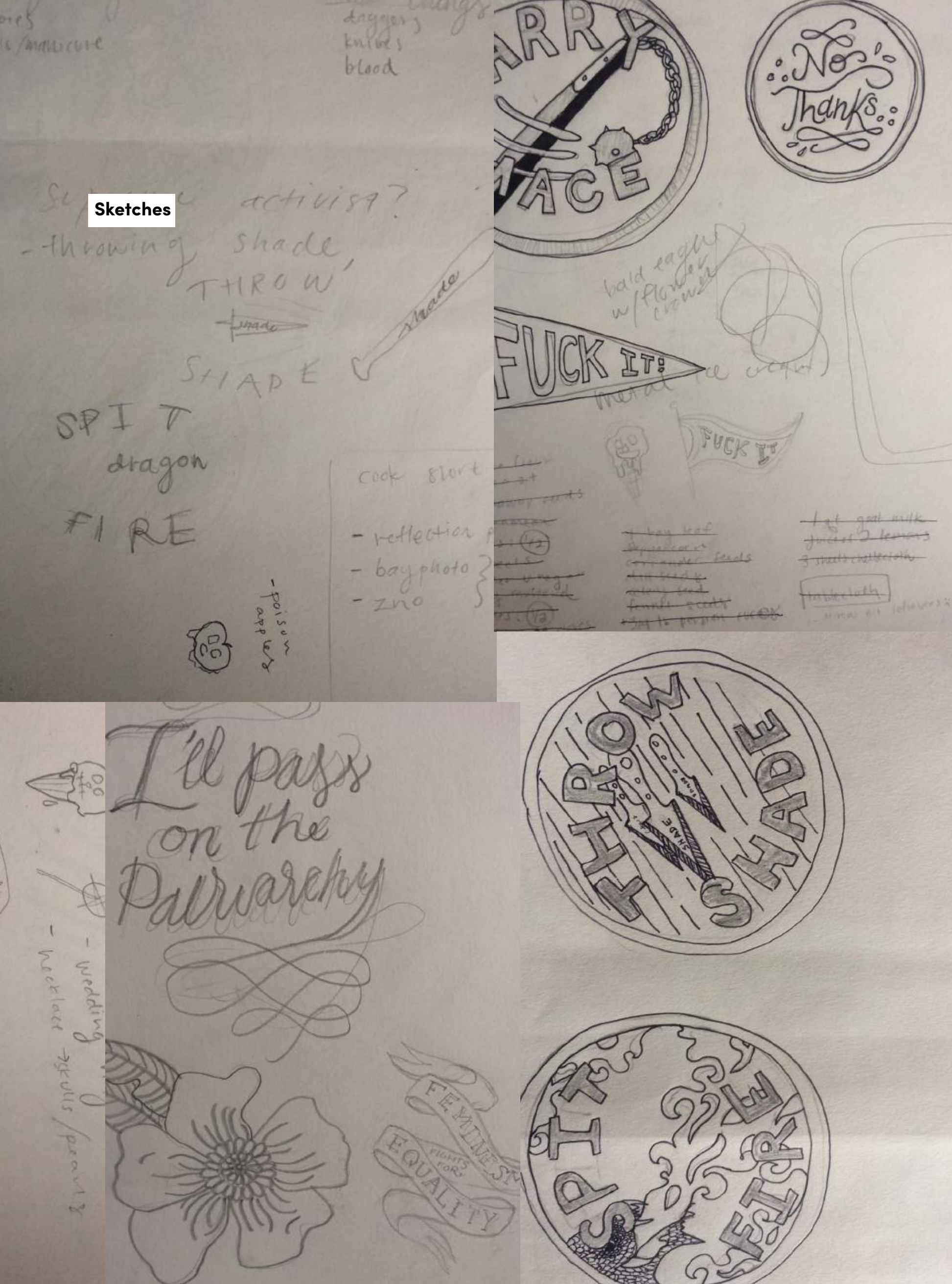




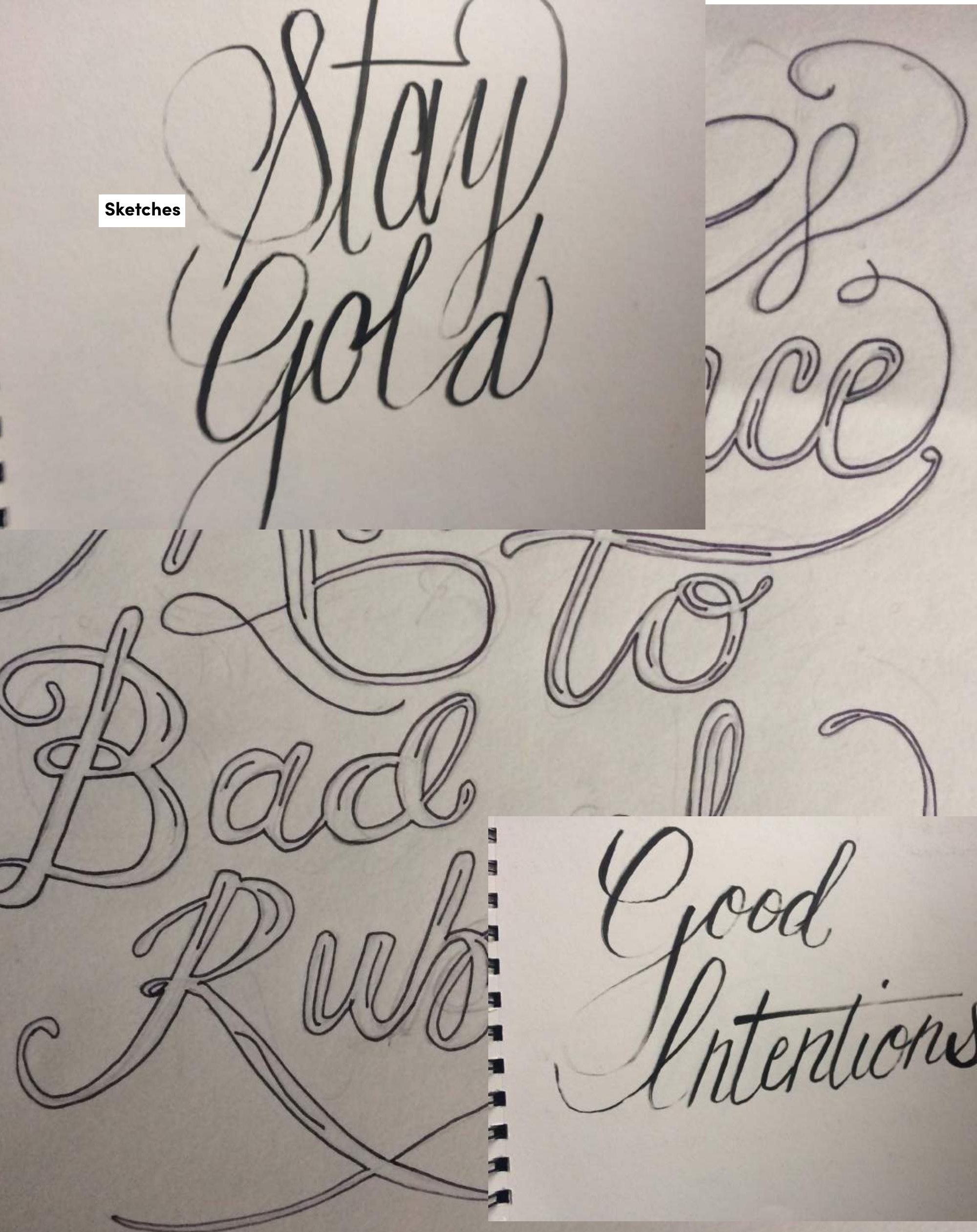


Final Images

Packaged Box 
Final Images

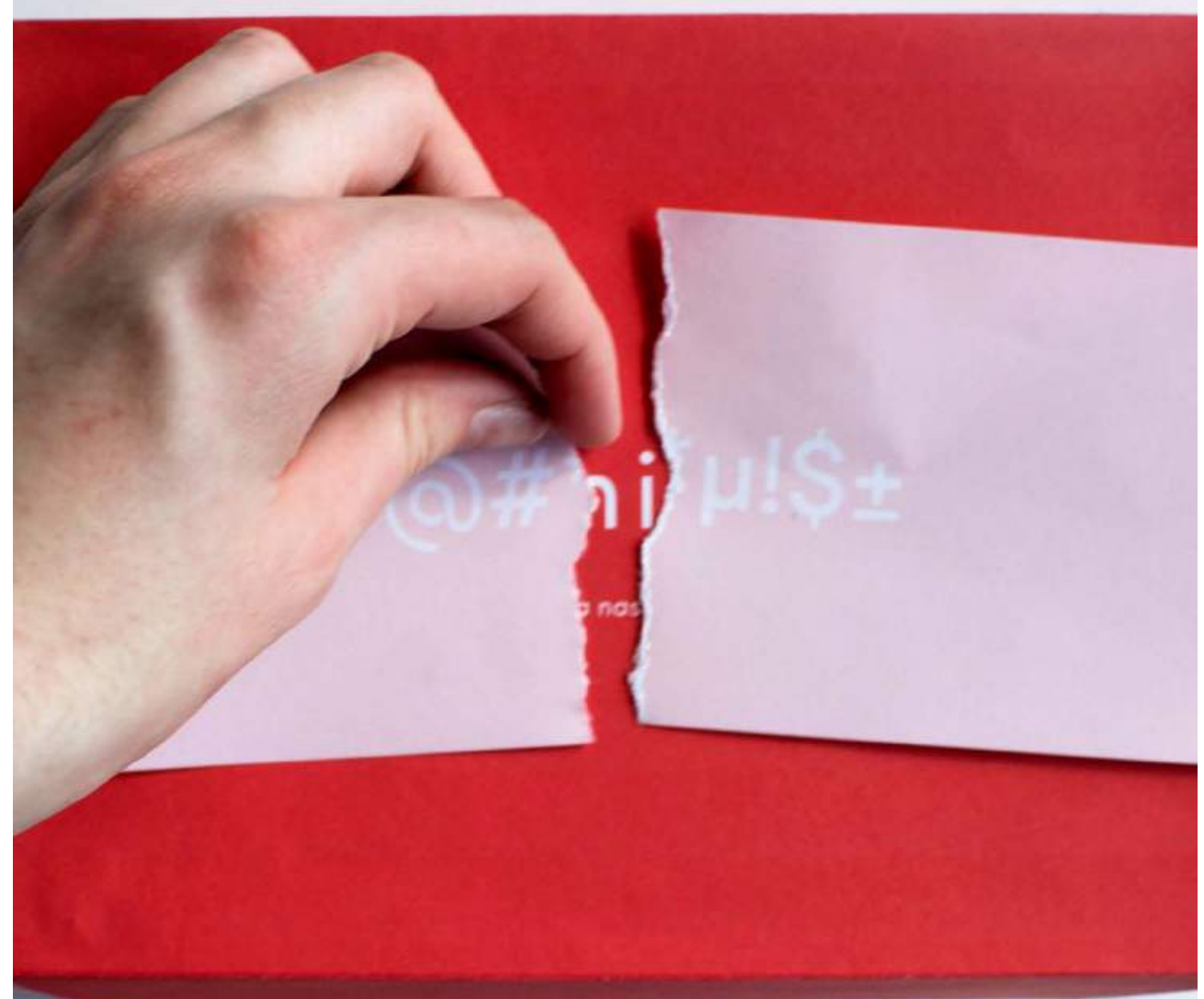




\section{Final Images}

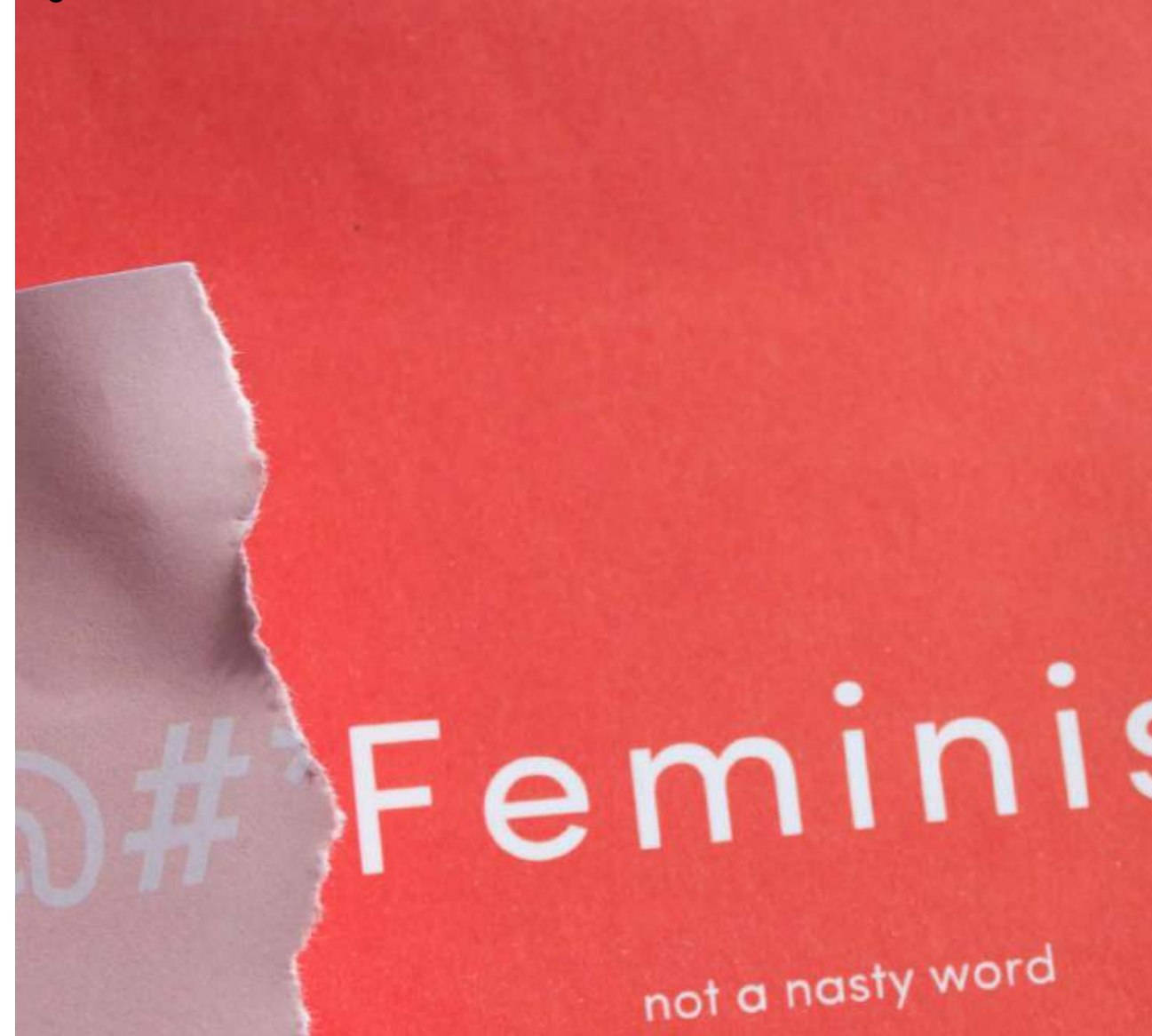


Final Images 
Final Images

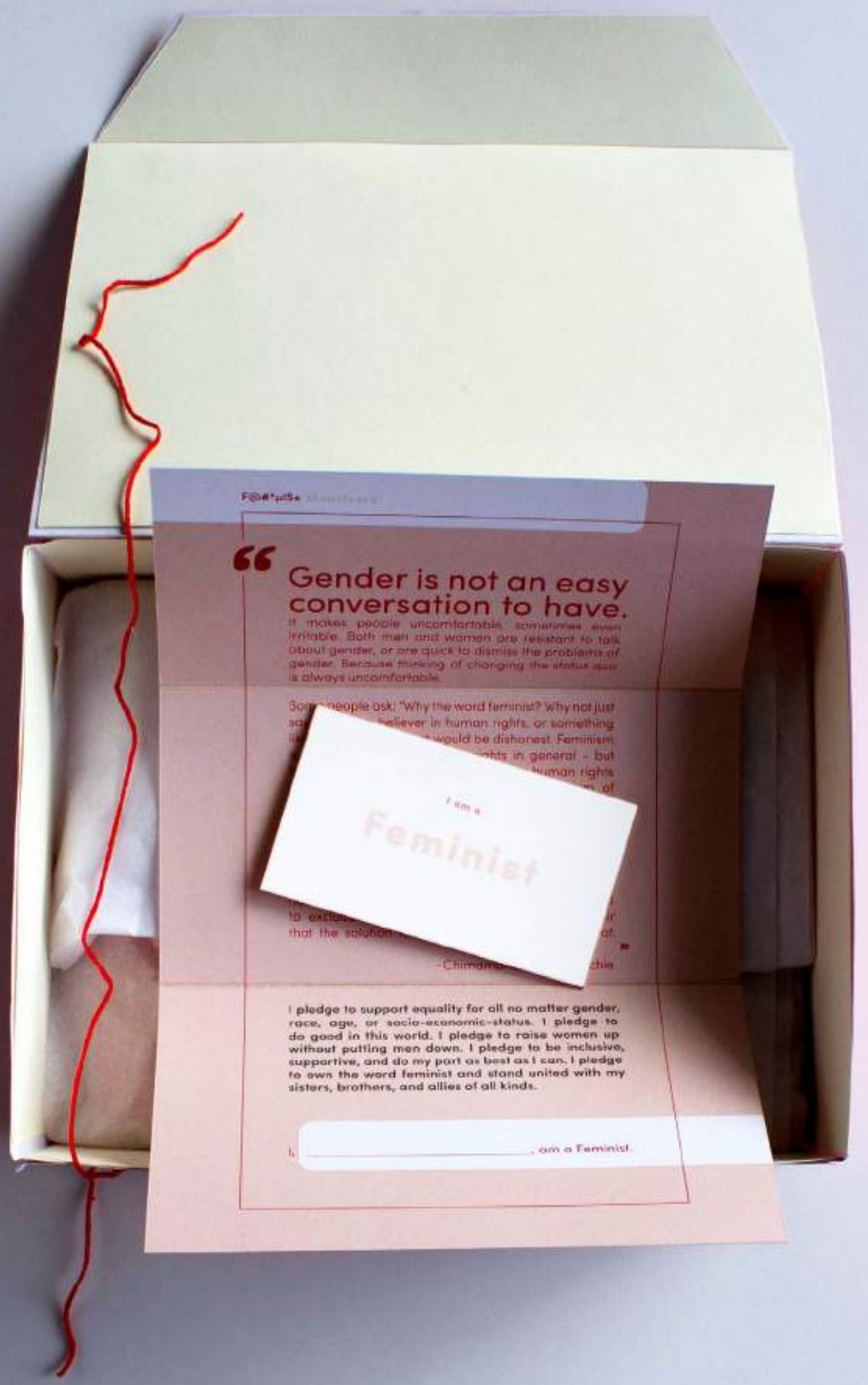

Manifesto and Carrying Card 
Final Images

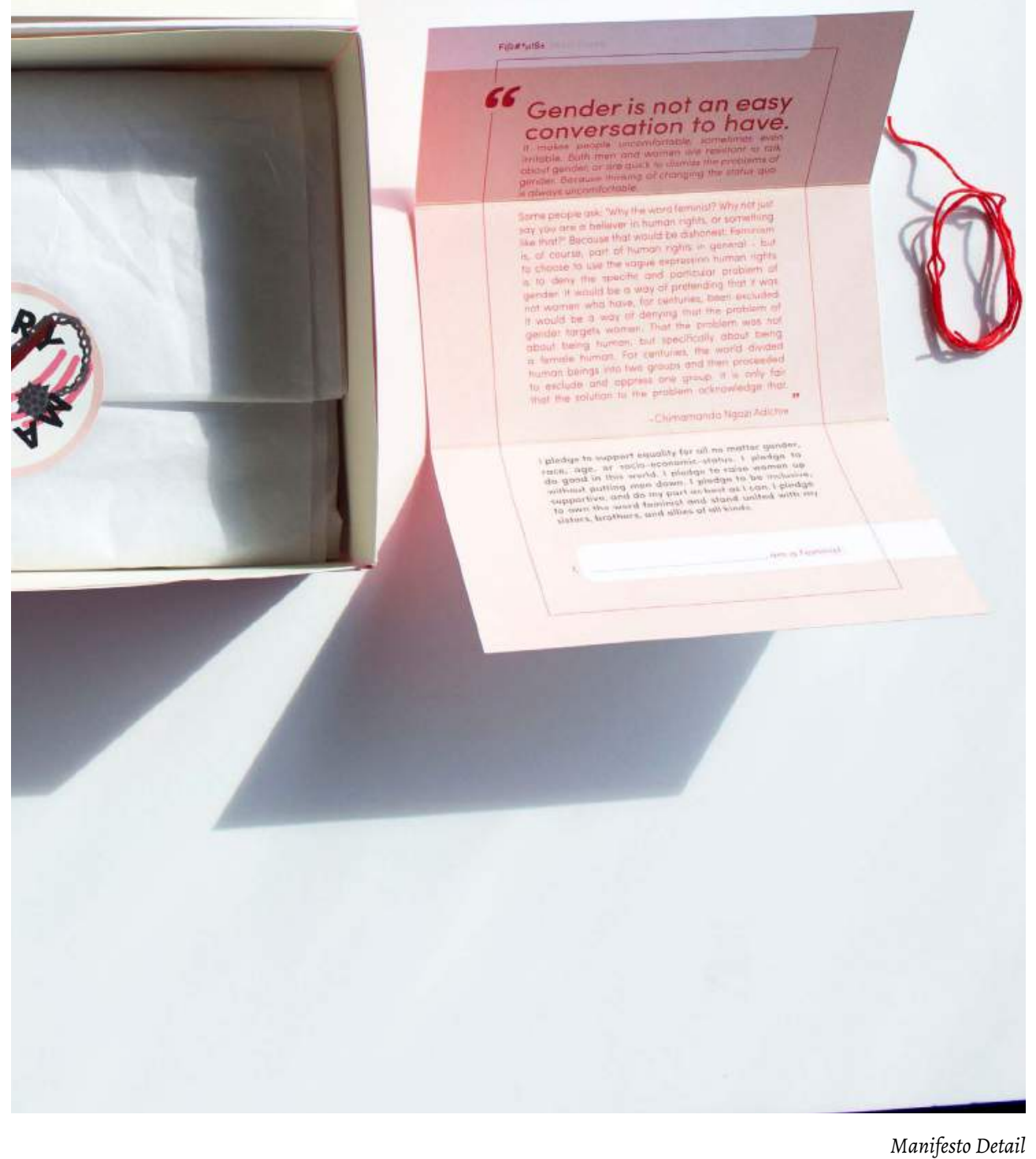


Final Images

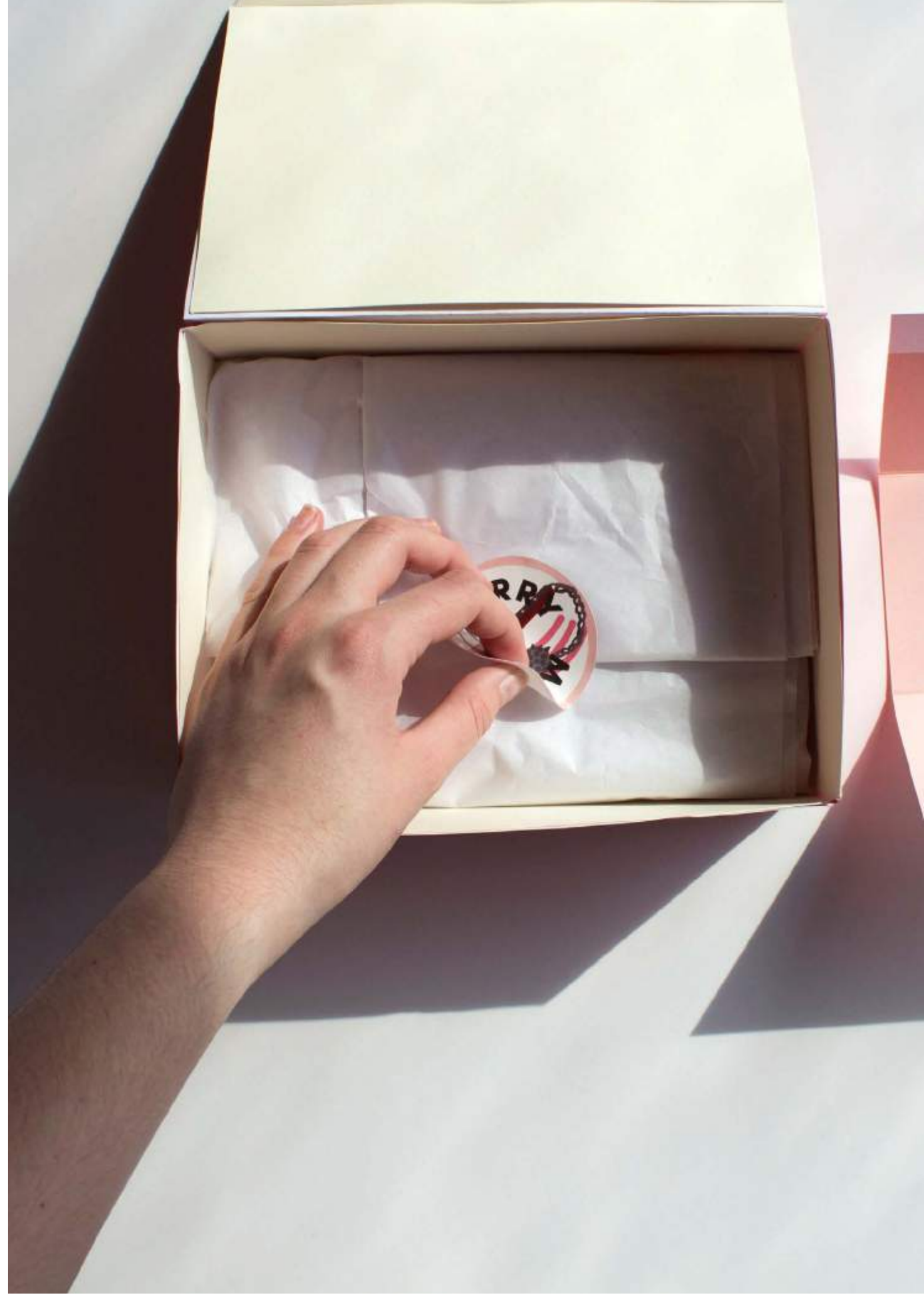

Tissue and Sticker 
Final Images

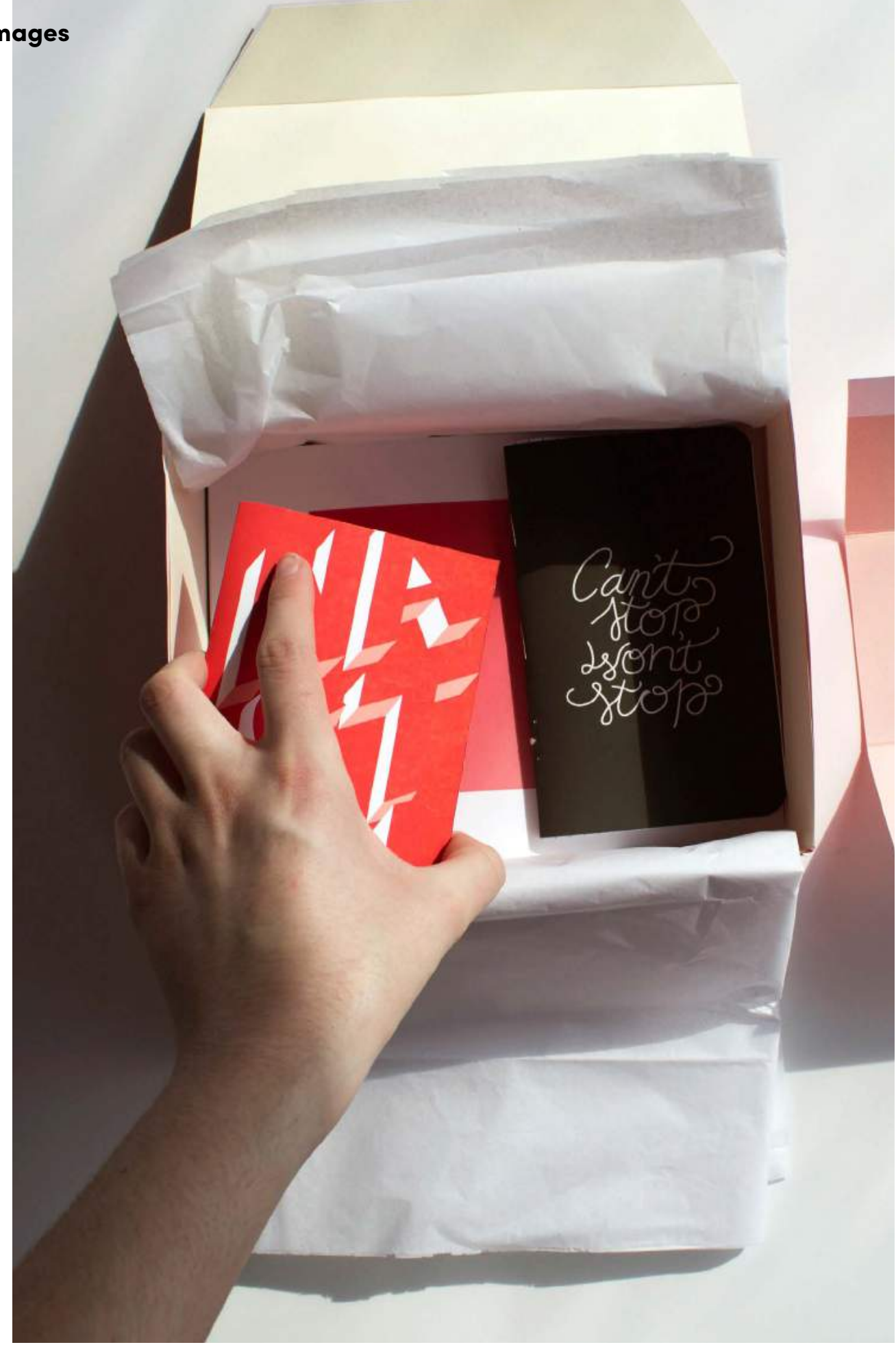

History Book (left) and Notebook (right) 
Final Images

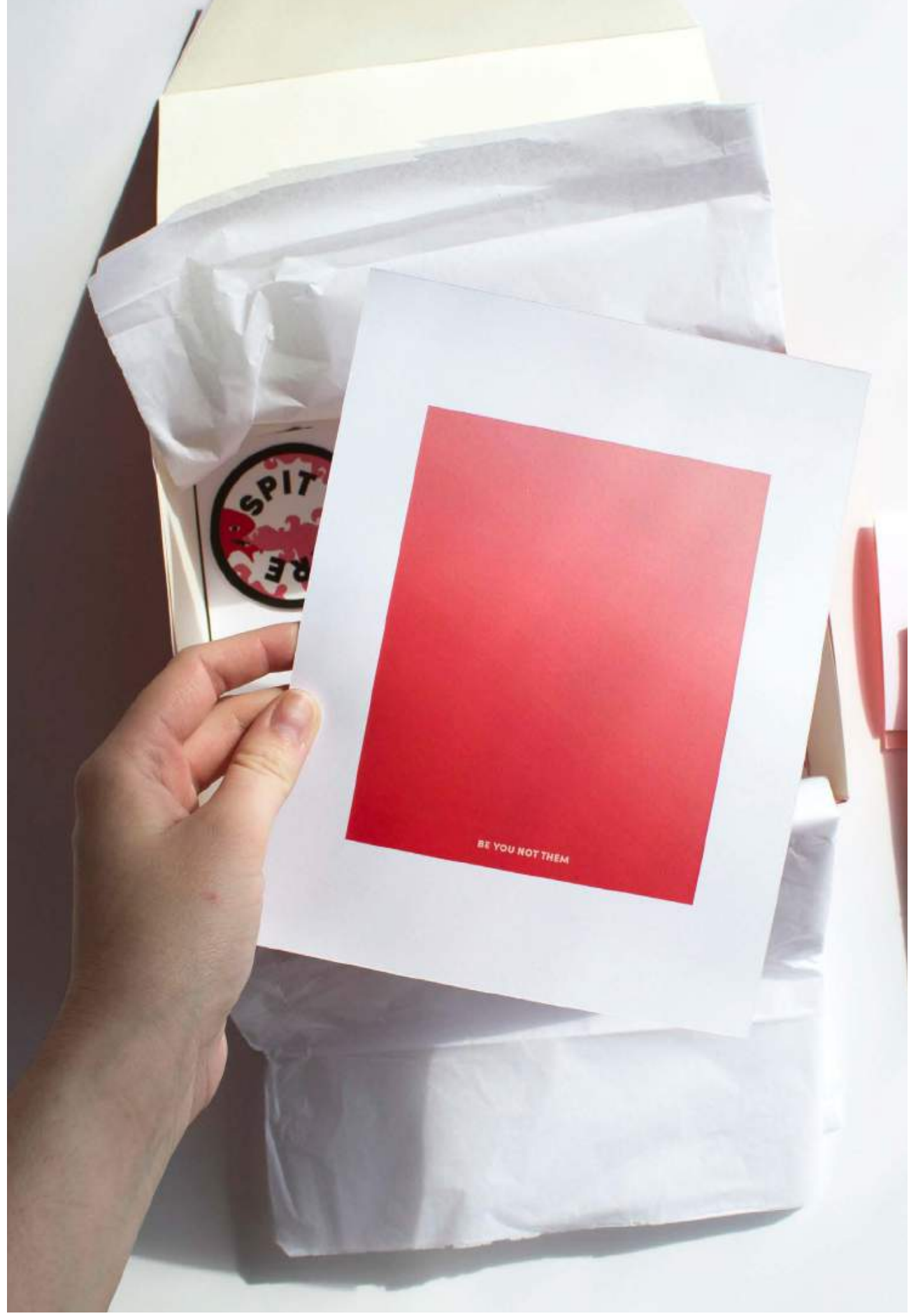

Print One: "Be You Not Them" 


\section{Final Images}

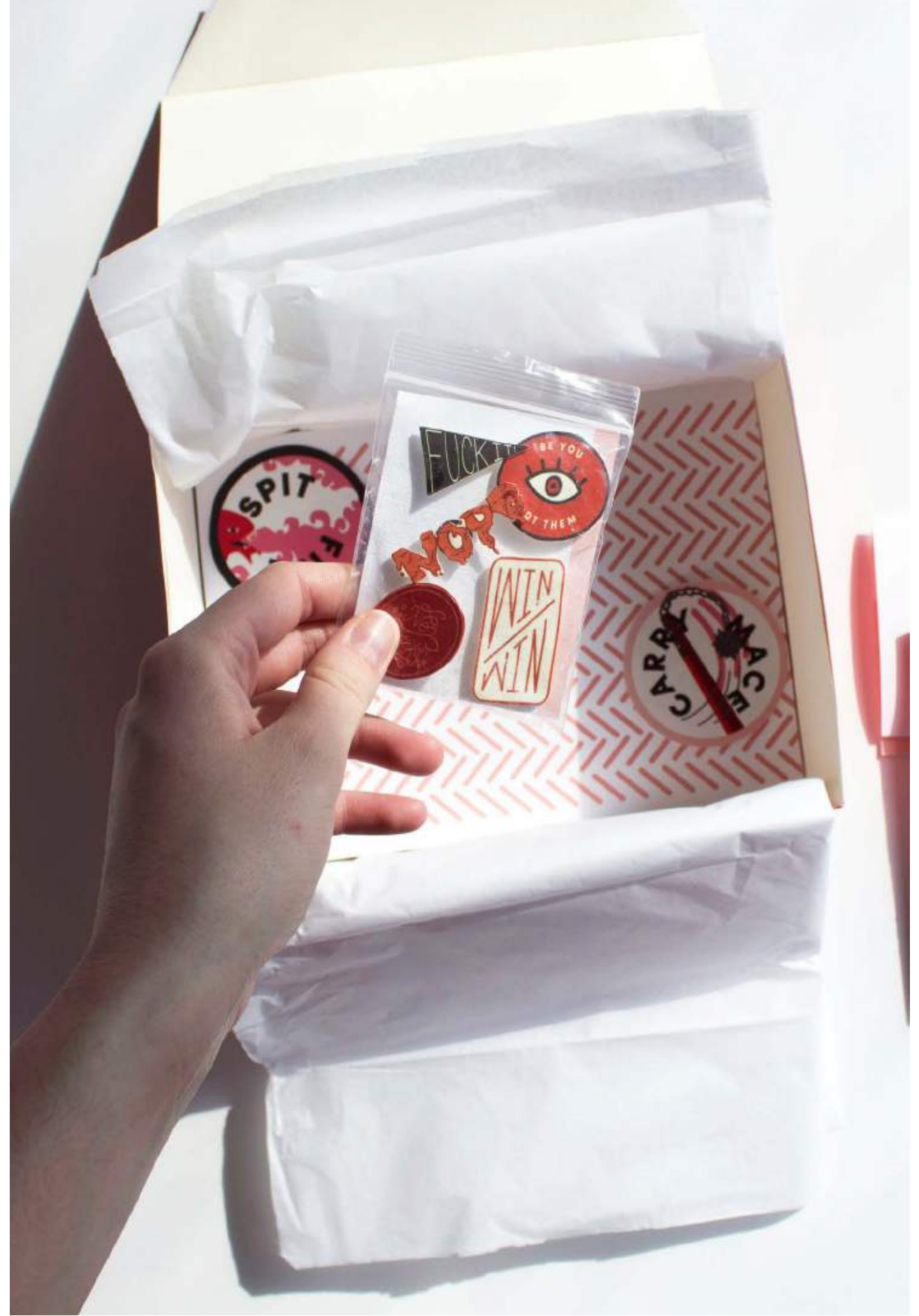




\section{Final Images}

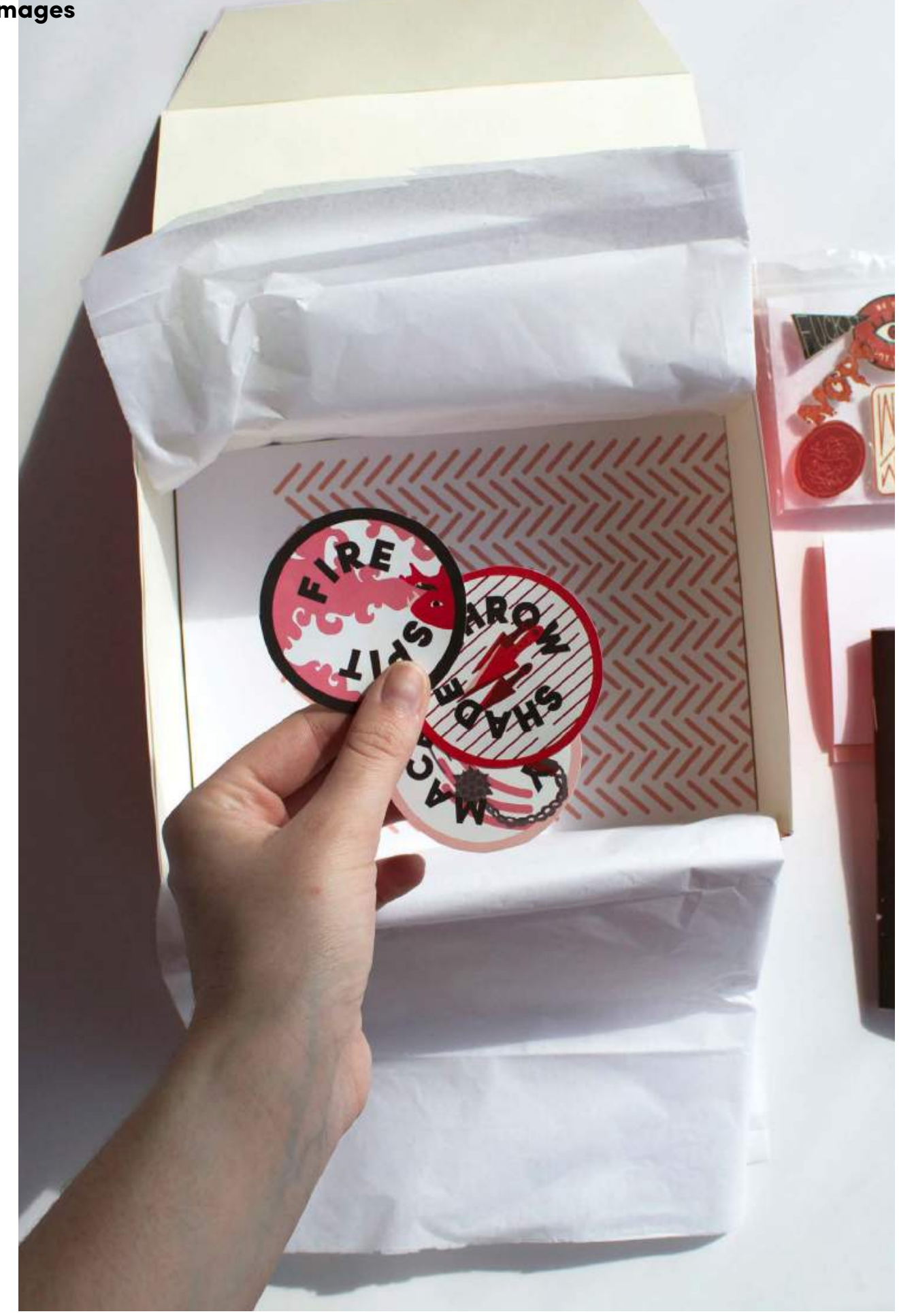

Stickers: "Spit Fire", "Throw Shade", "Carry Mace" 


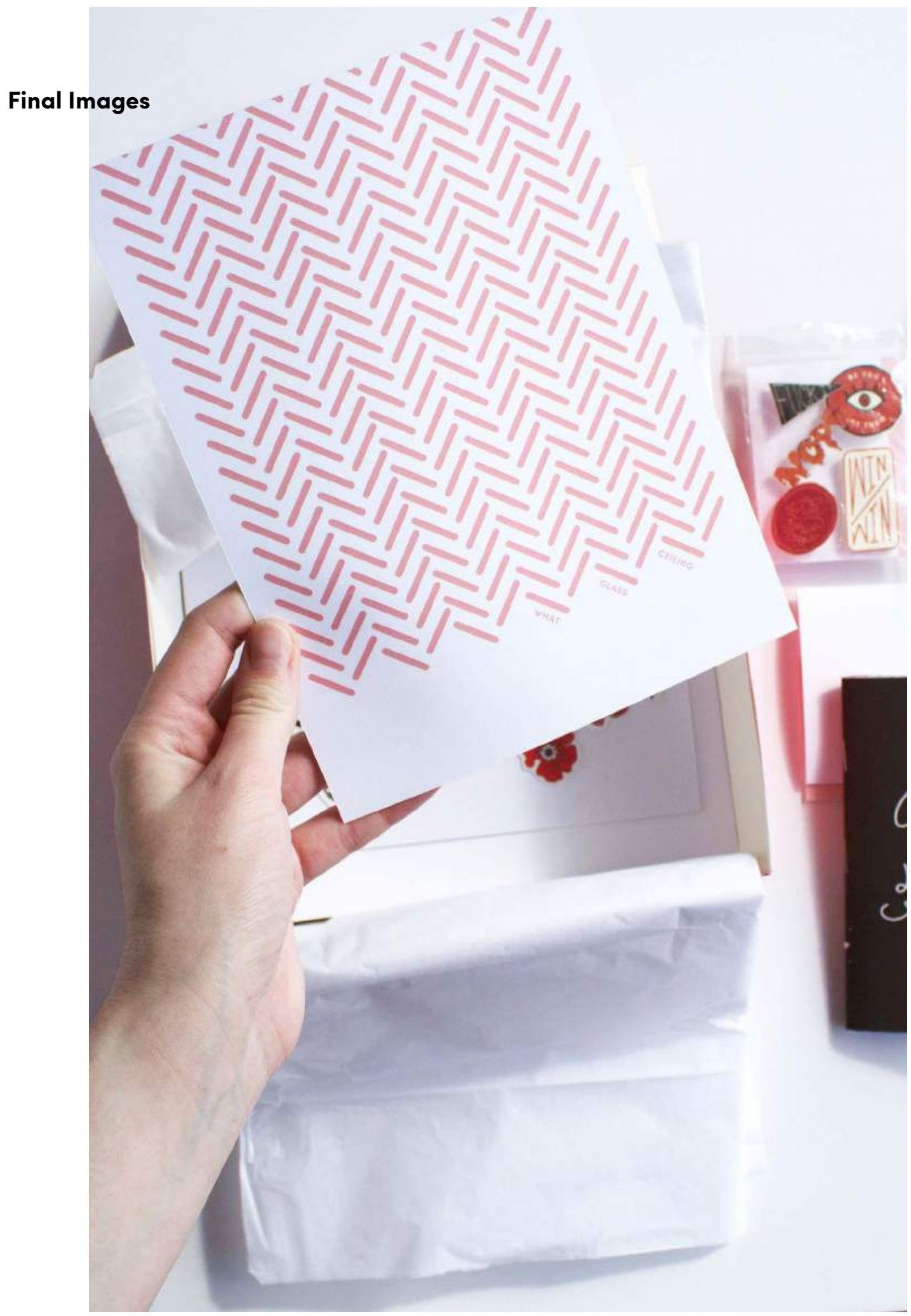

Print Two: "What Glass Celing" 
Final Images

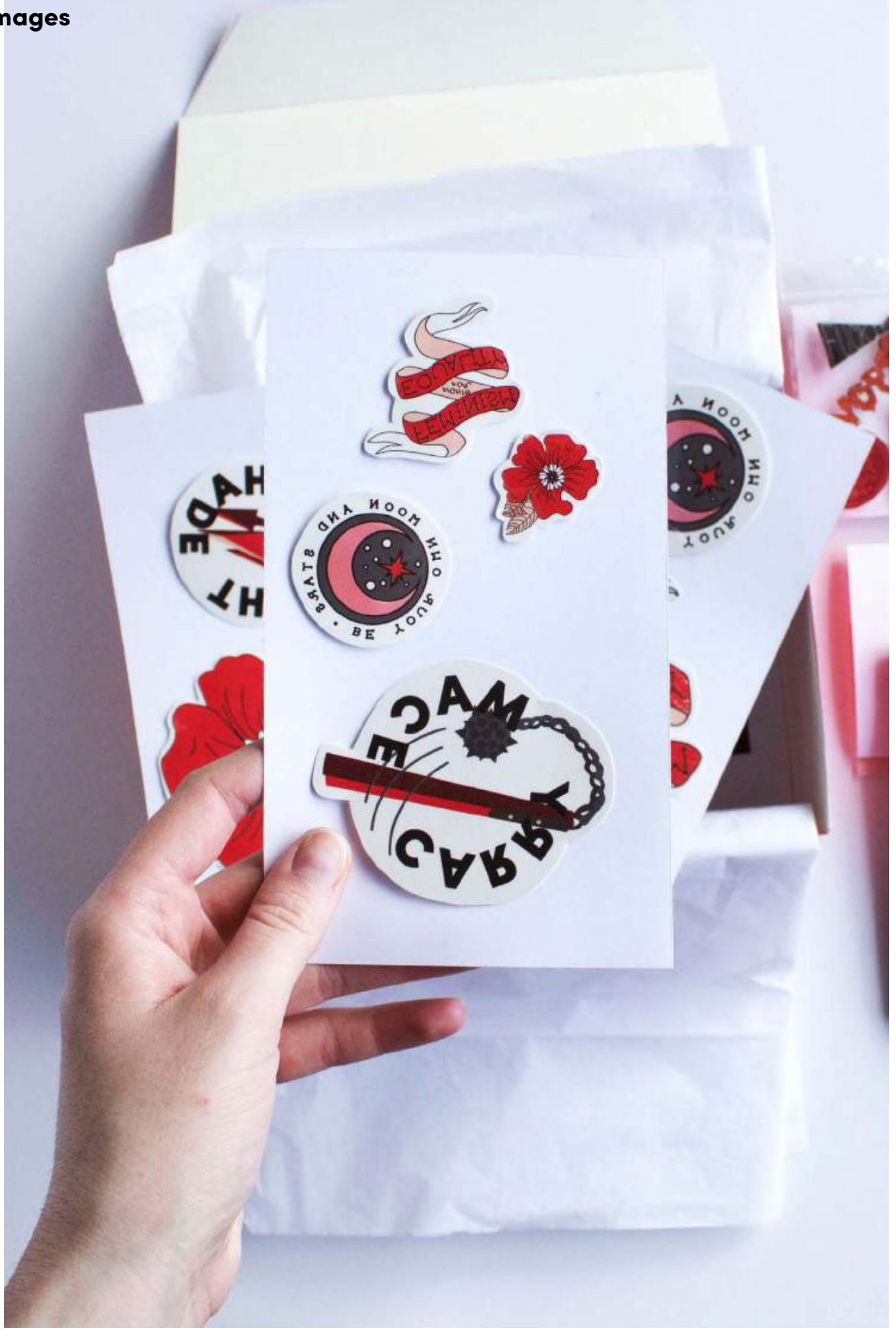

Temporary Tattoos 


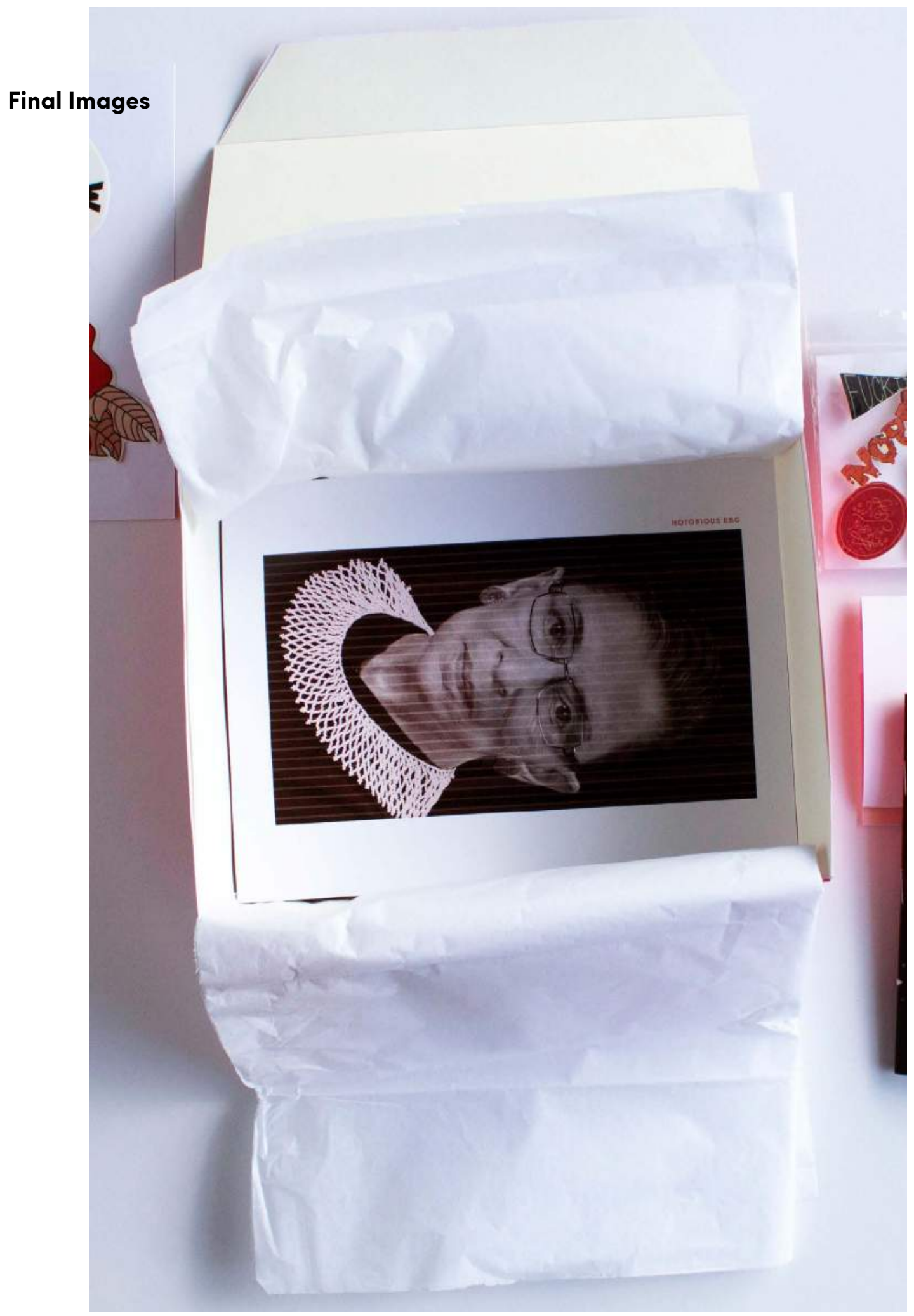

Print Three: Notorious RBG 
Final Images

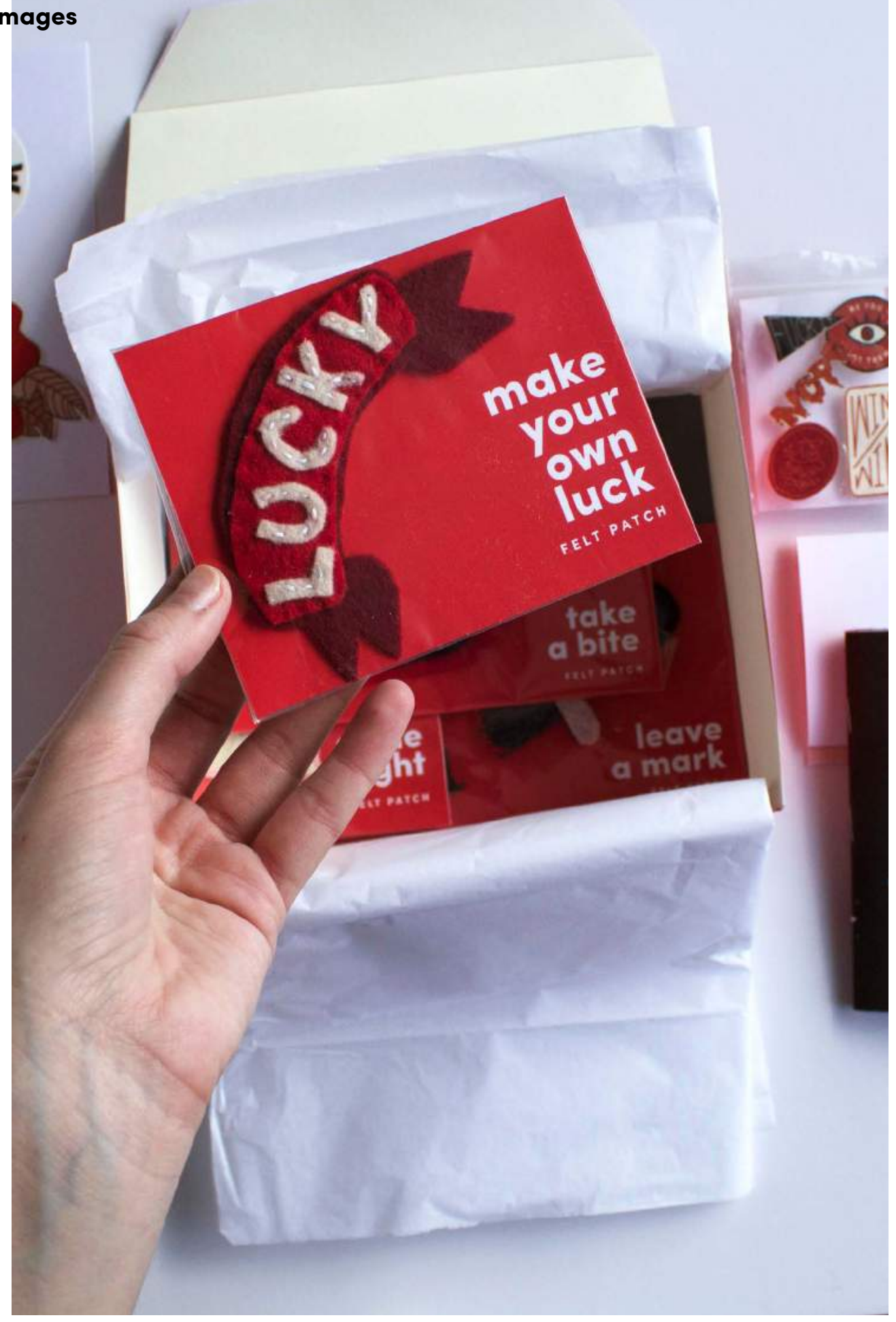

Patches: Lucky 


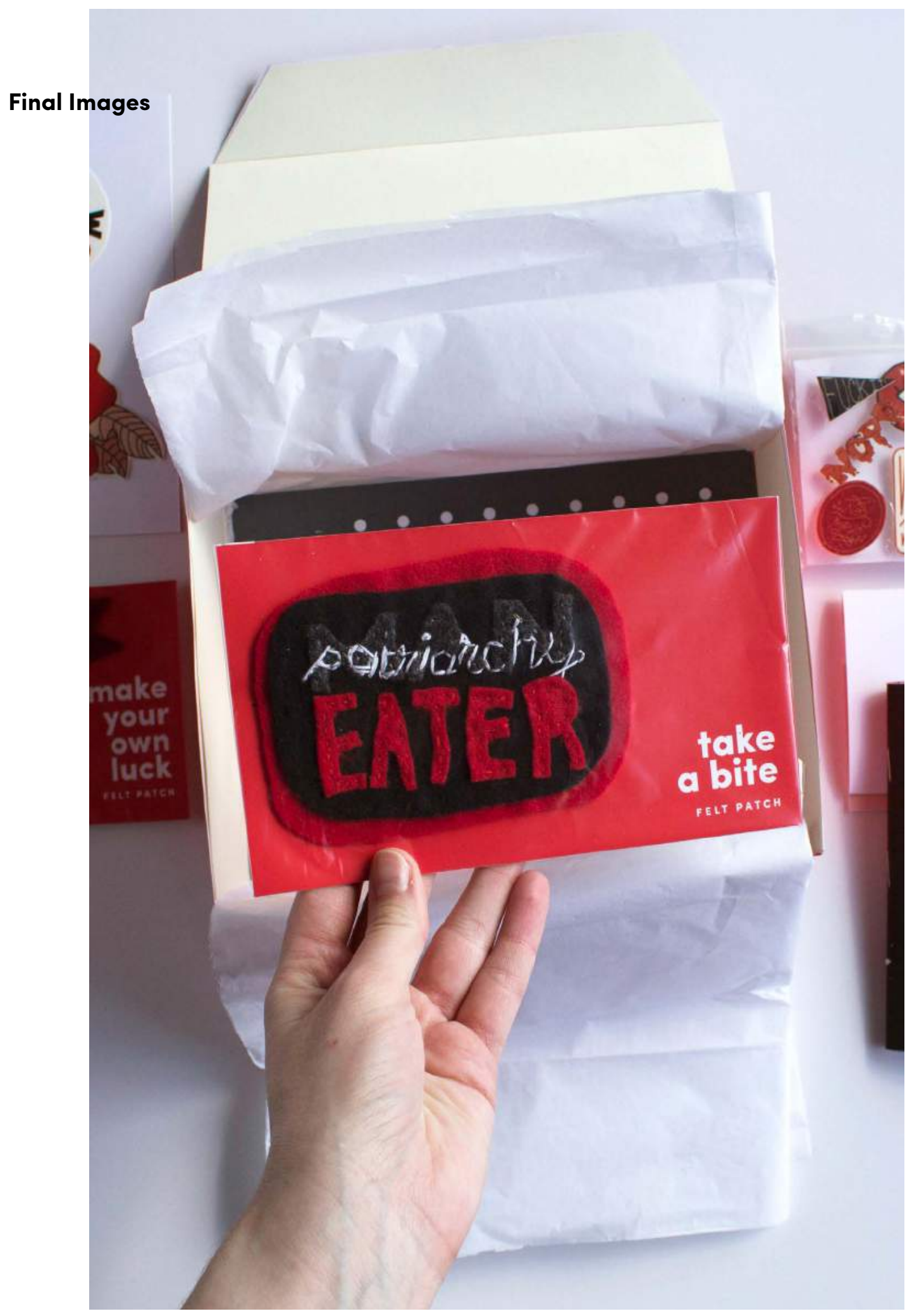

Patches: Patriarchy Eater 
Final Images

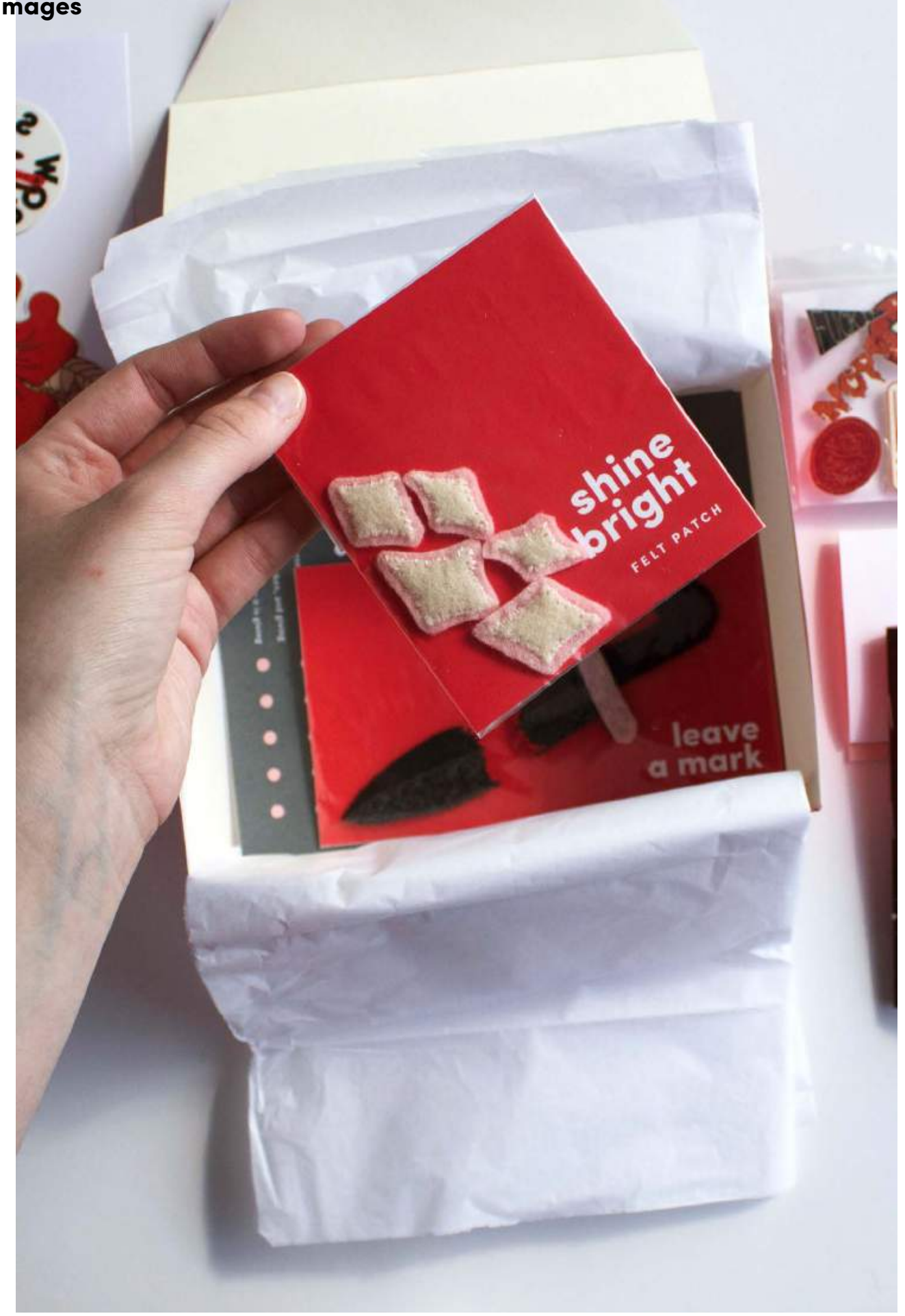

Patches: Sparkles 
Final Images

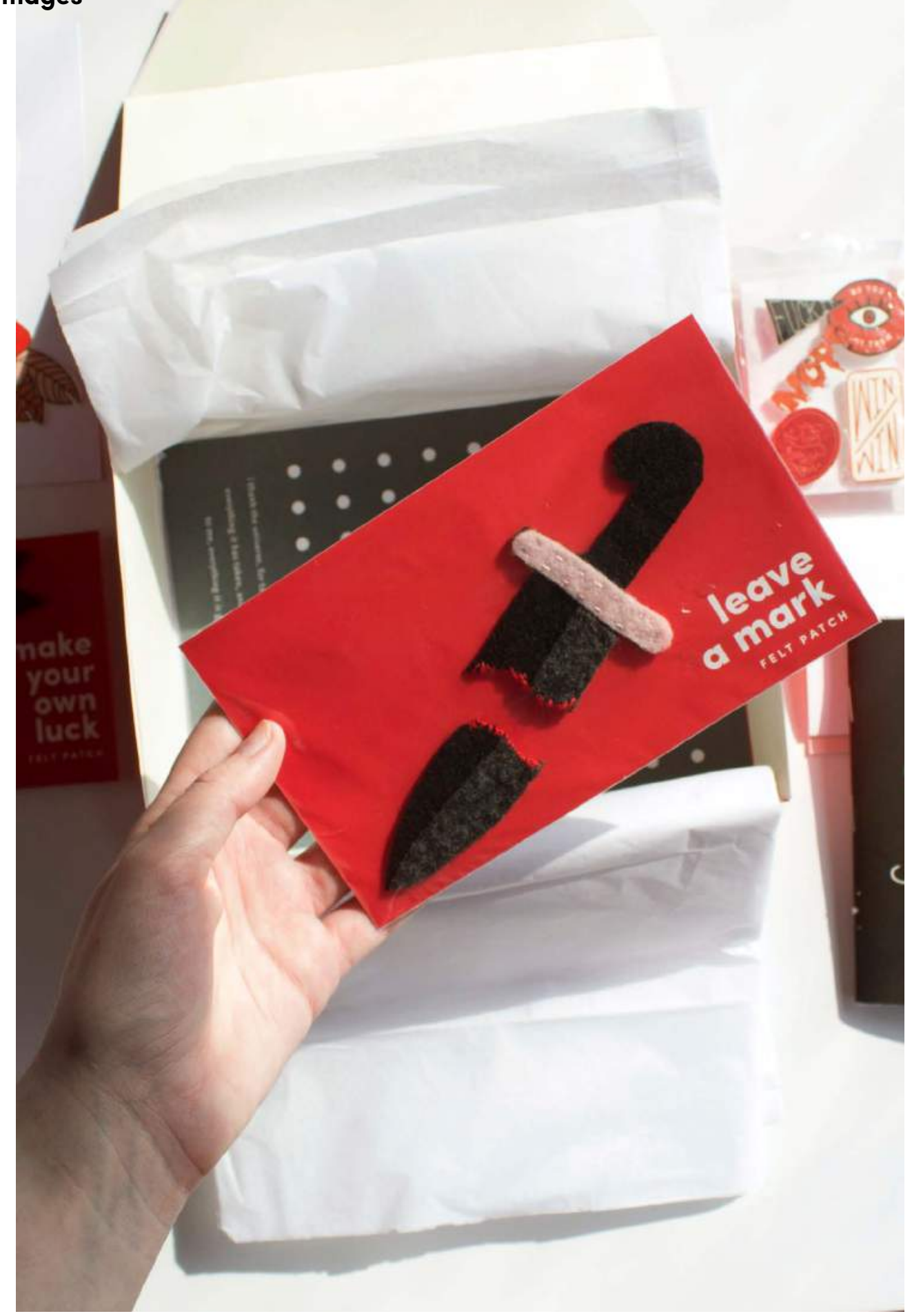

Patches: Dagger 
Final Images

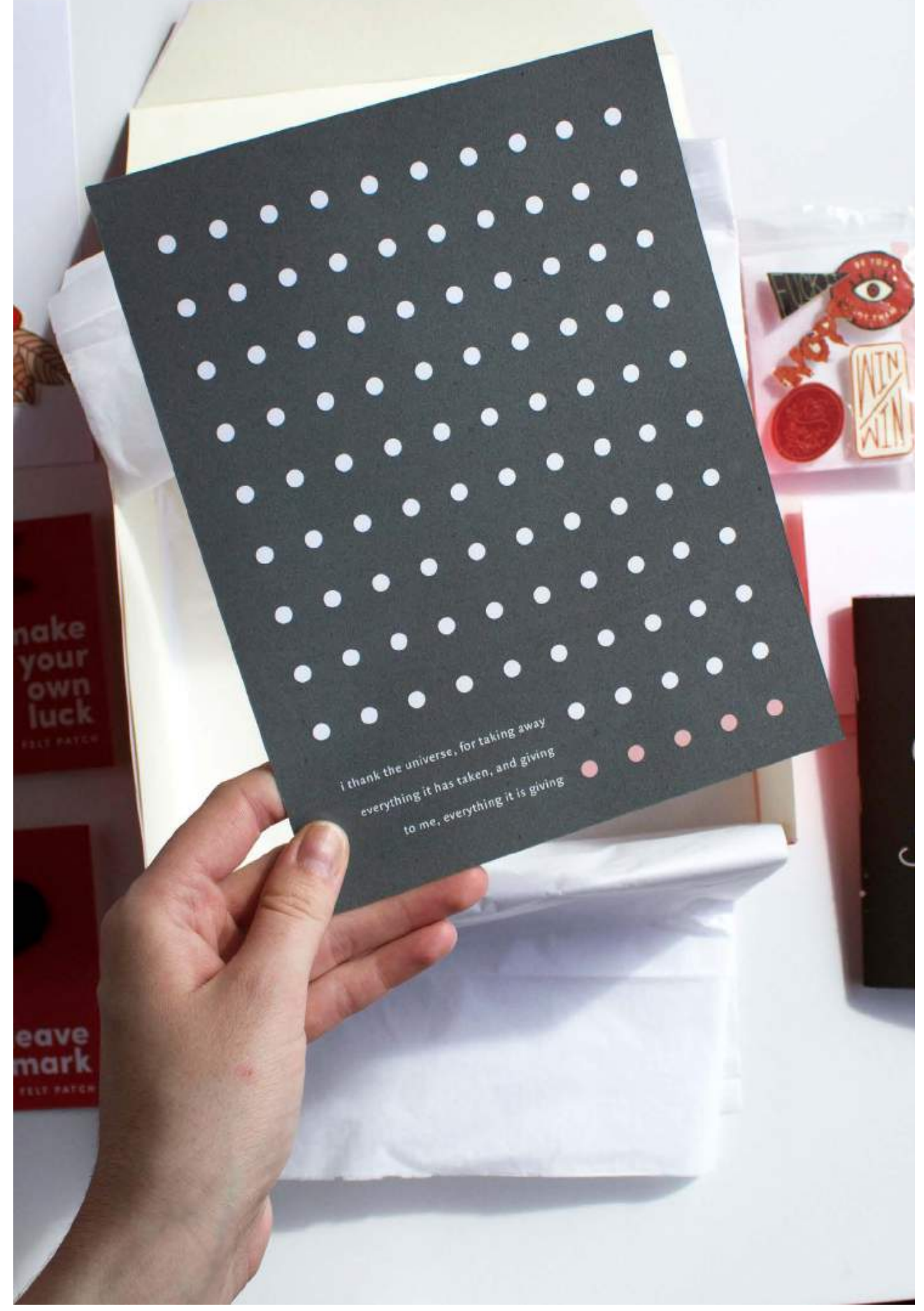

Print Three: Only 5/100 CEOs are Female 
Final Images

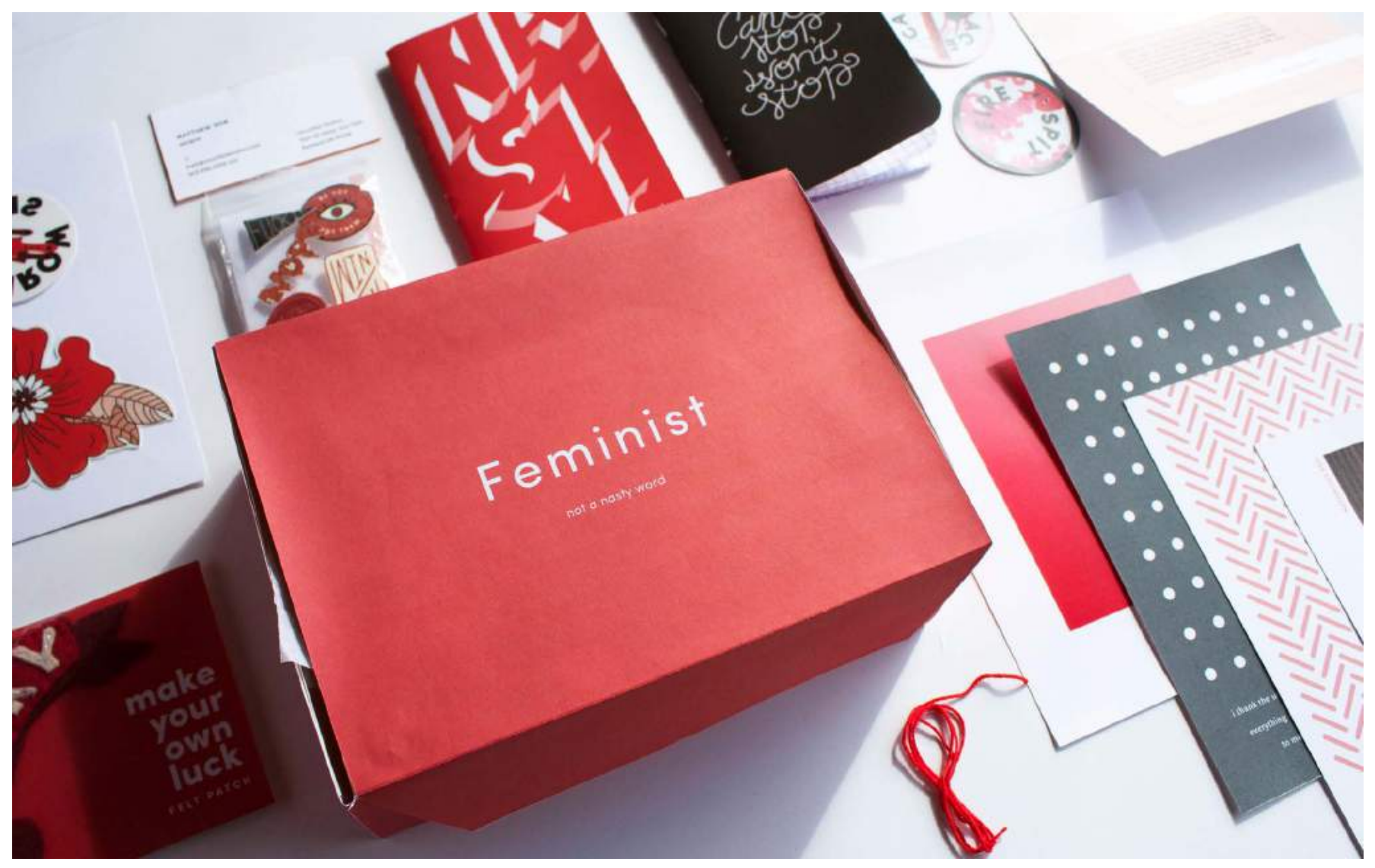

Assembled Kit 
Final Images

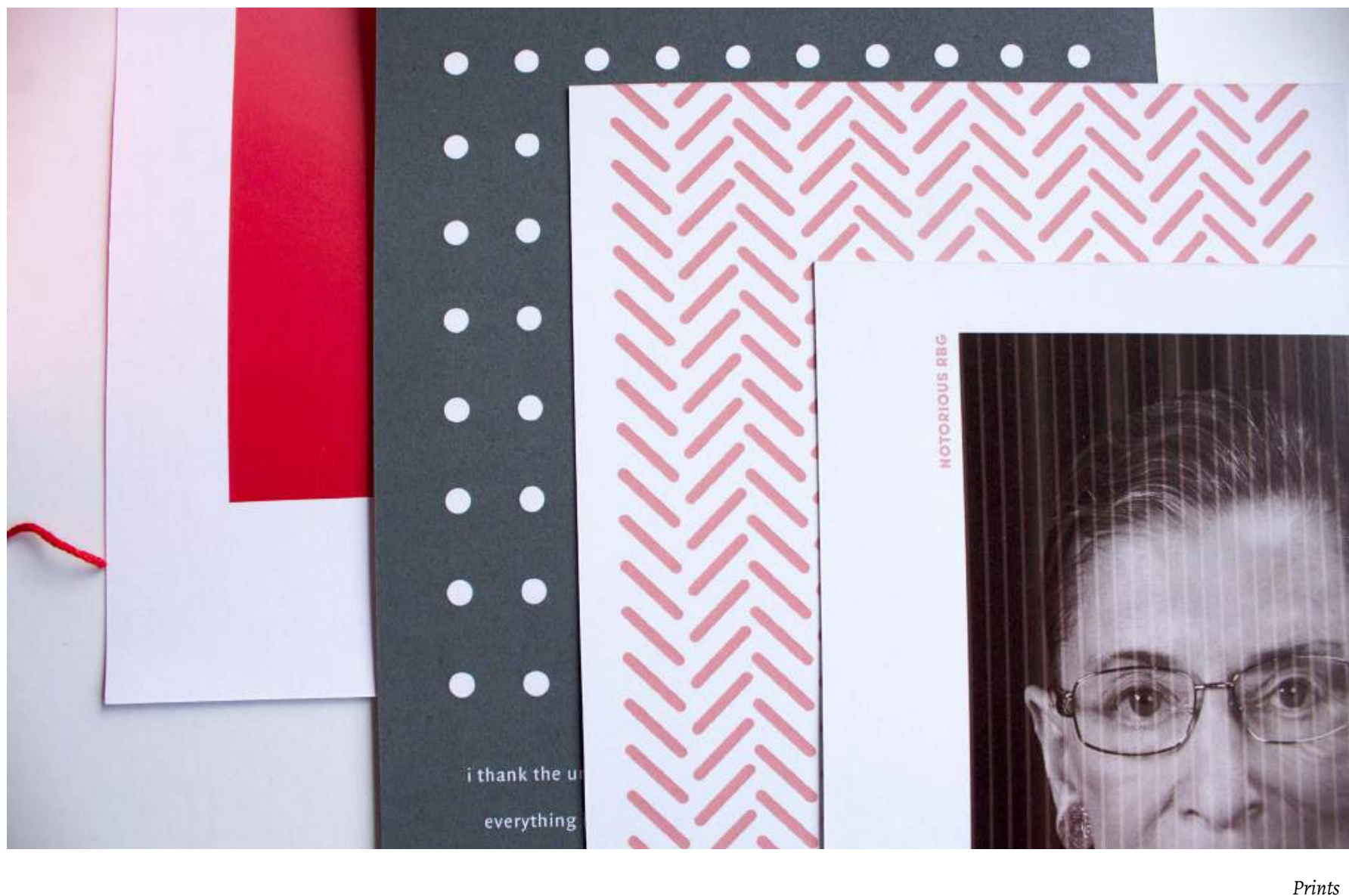


Final Images

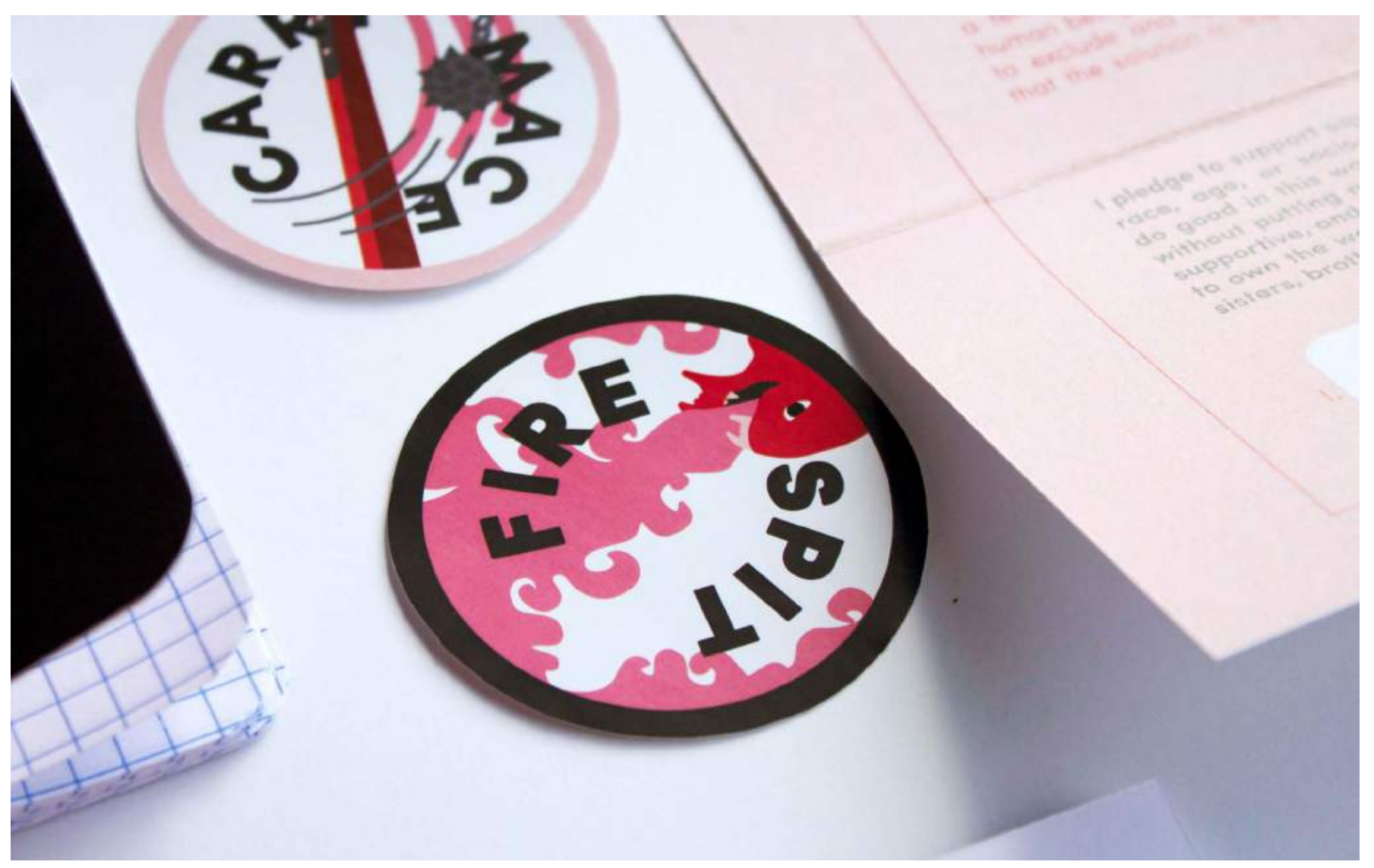

Stickers 


\section{Final Images}
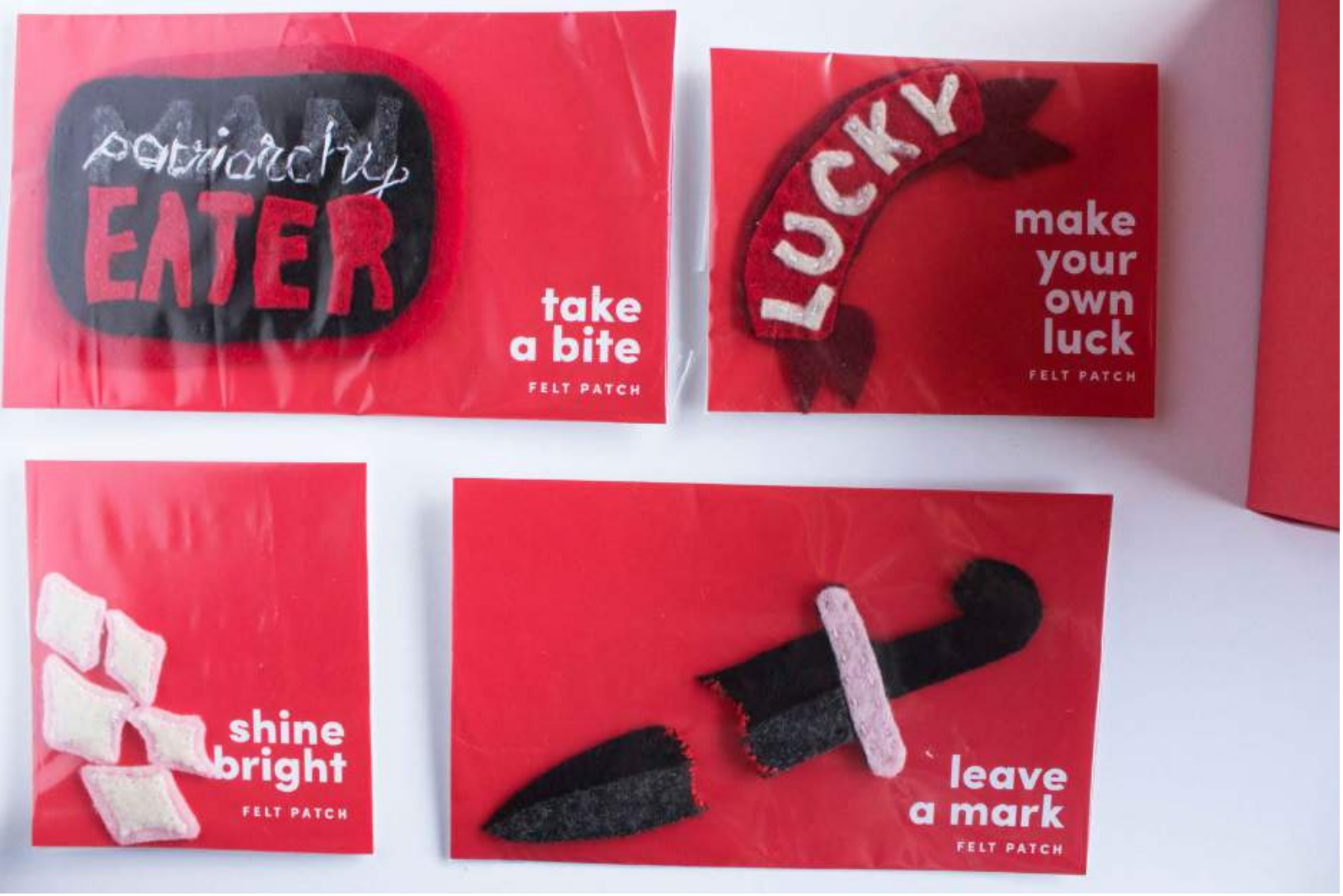
Final Images

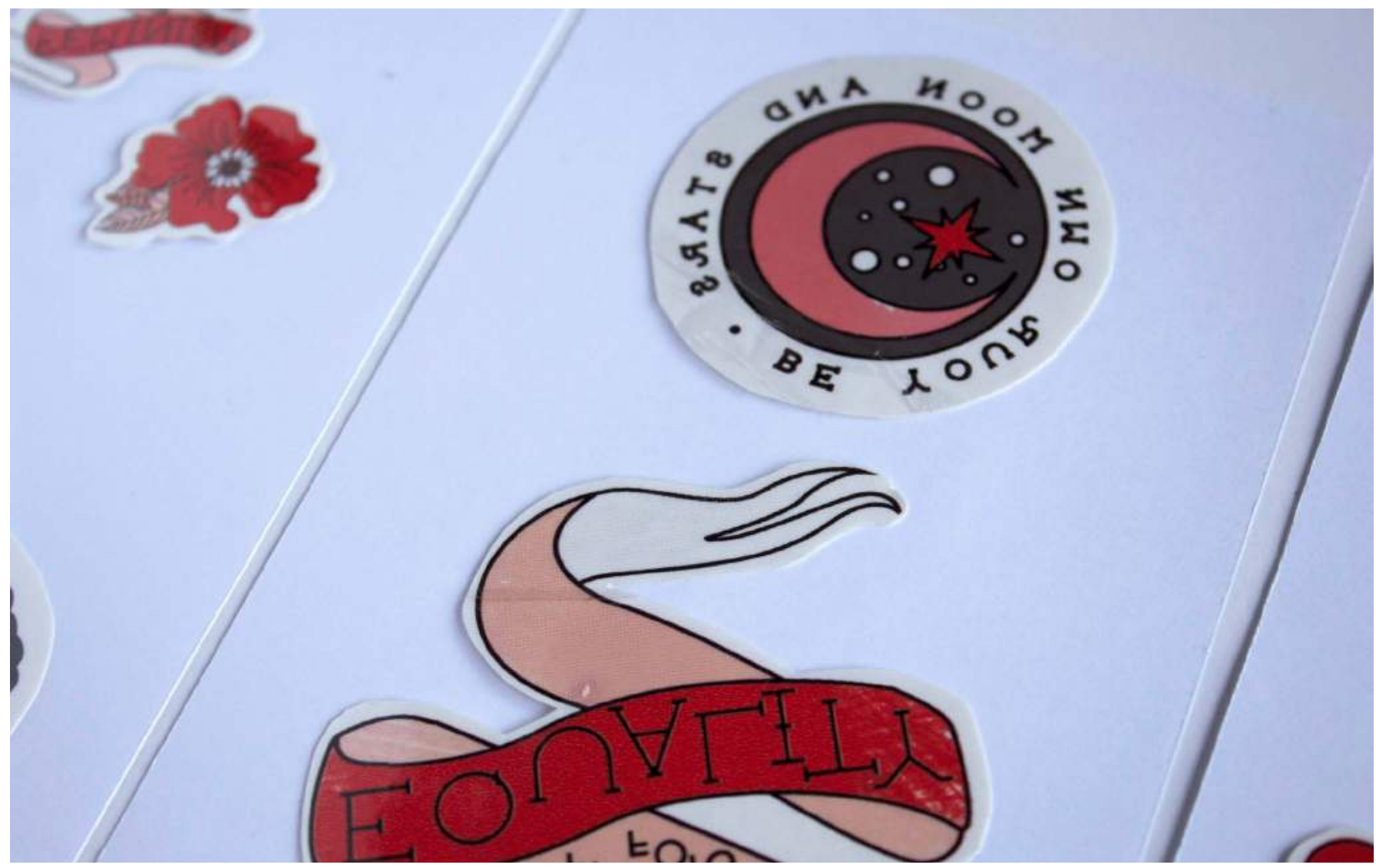

Temporary Tattoos 
Final Images

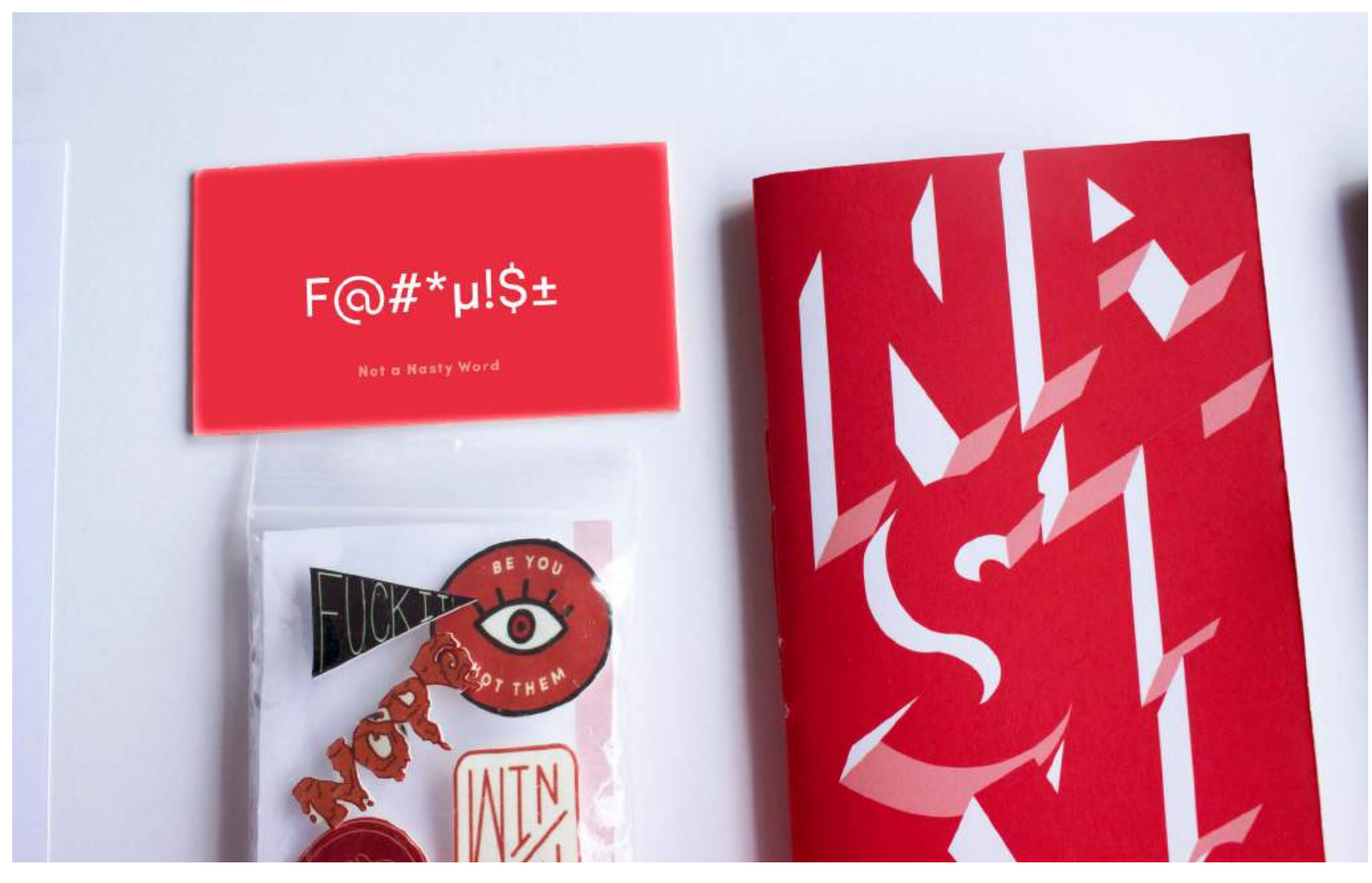

Carrying Card Detail 
Final Images

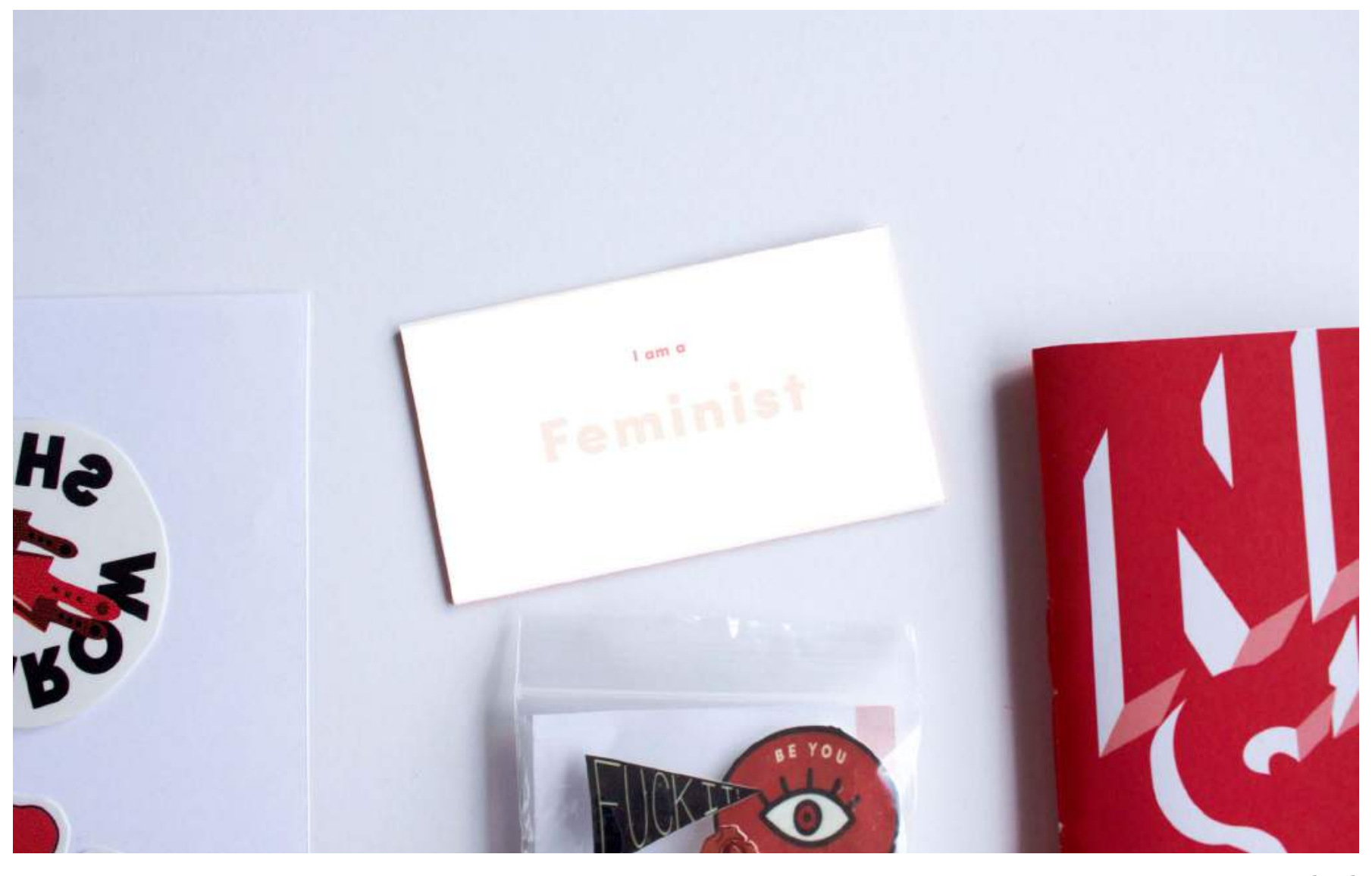

Carrying Card Back 
Final Images

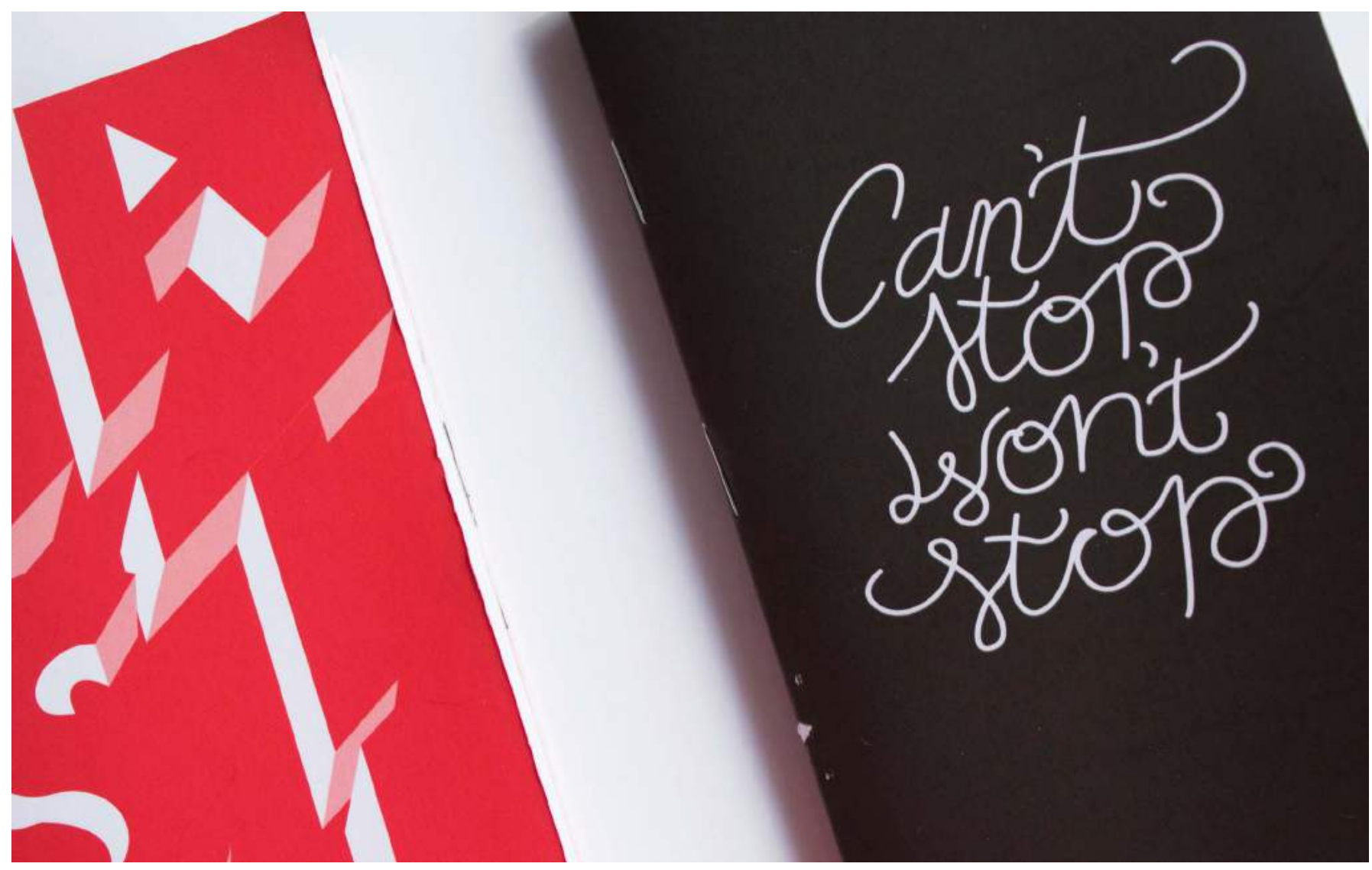




\section{Final Images}

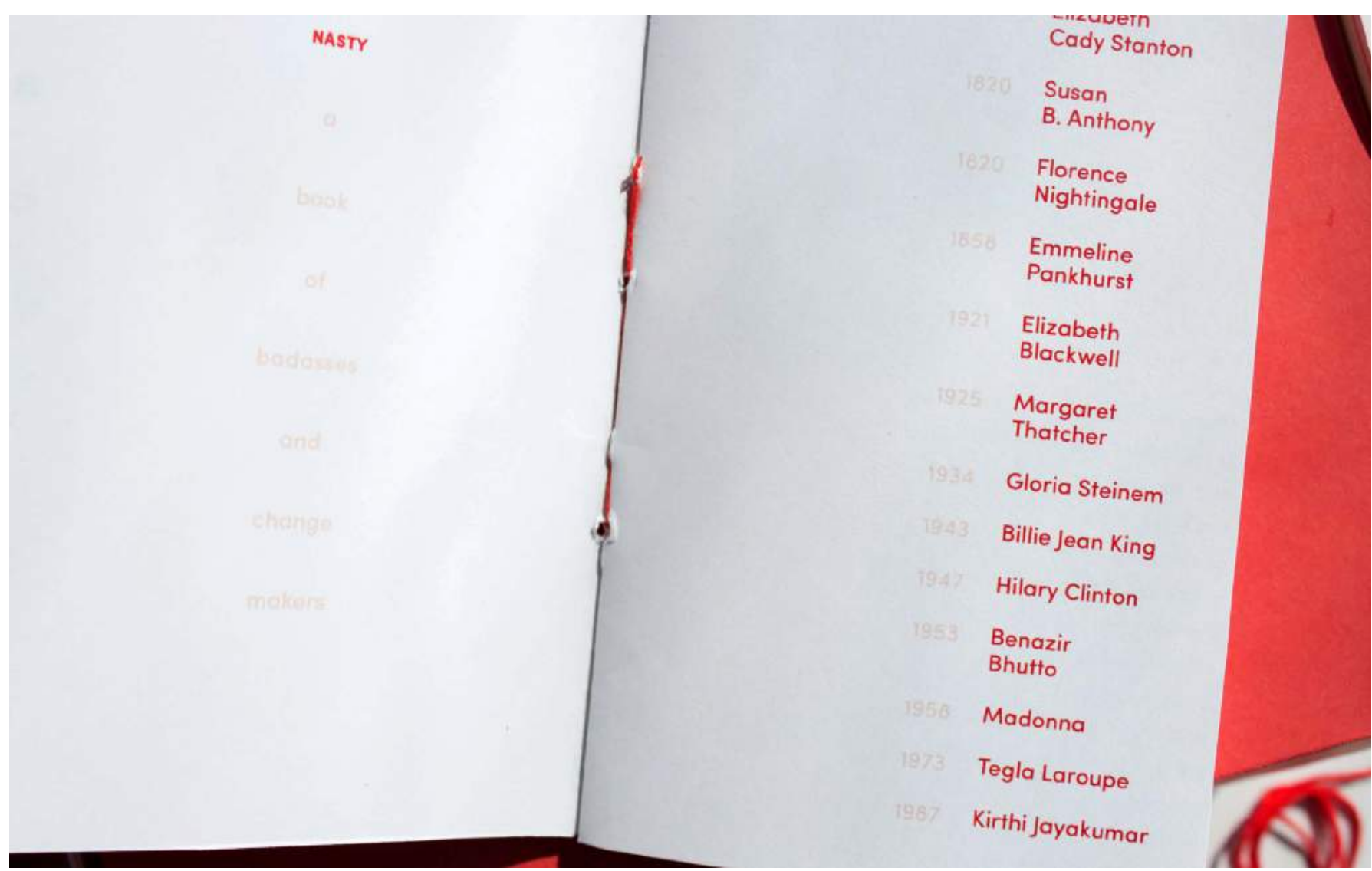

History Book Interior Spread 
Final Images
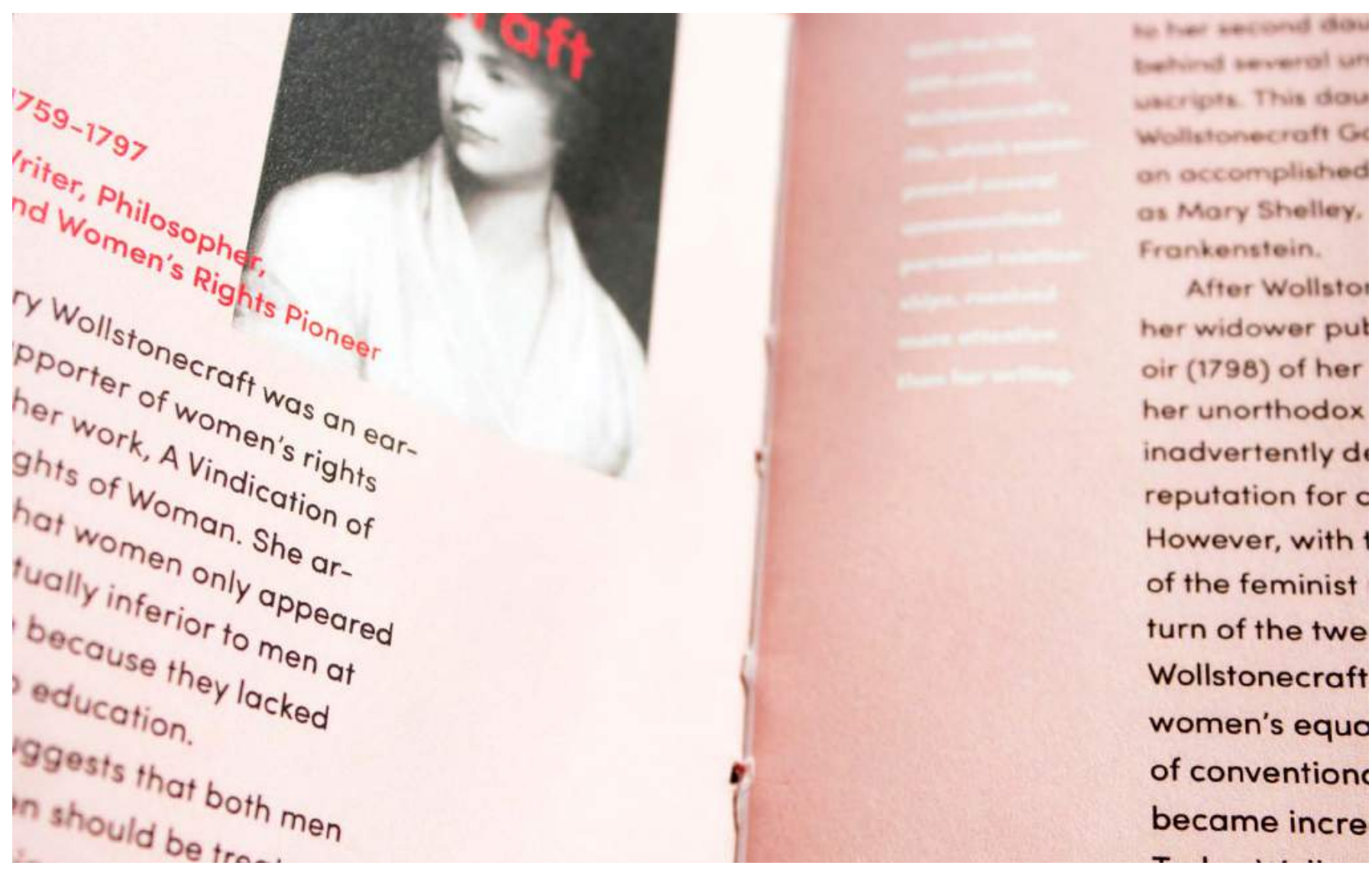


\section{Final Images}

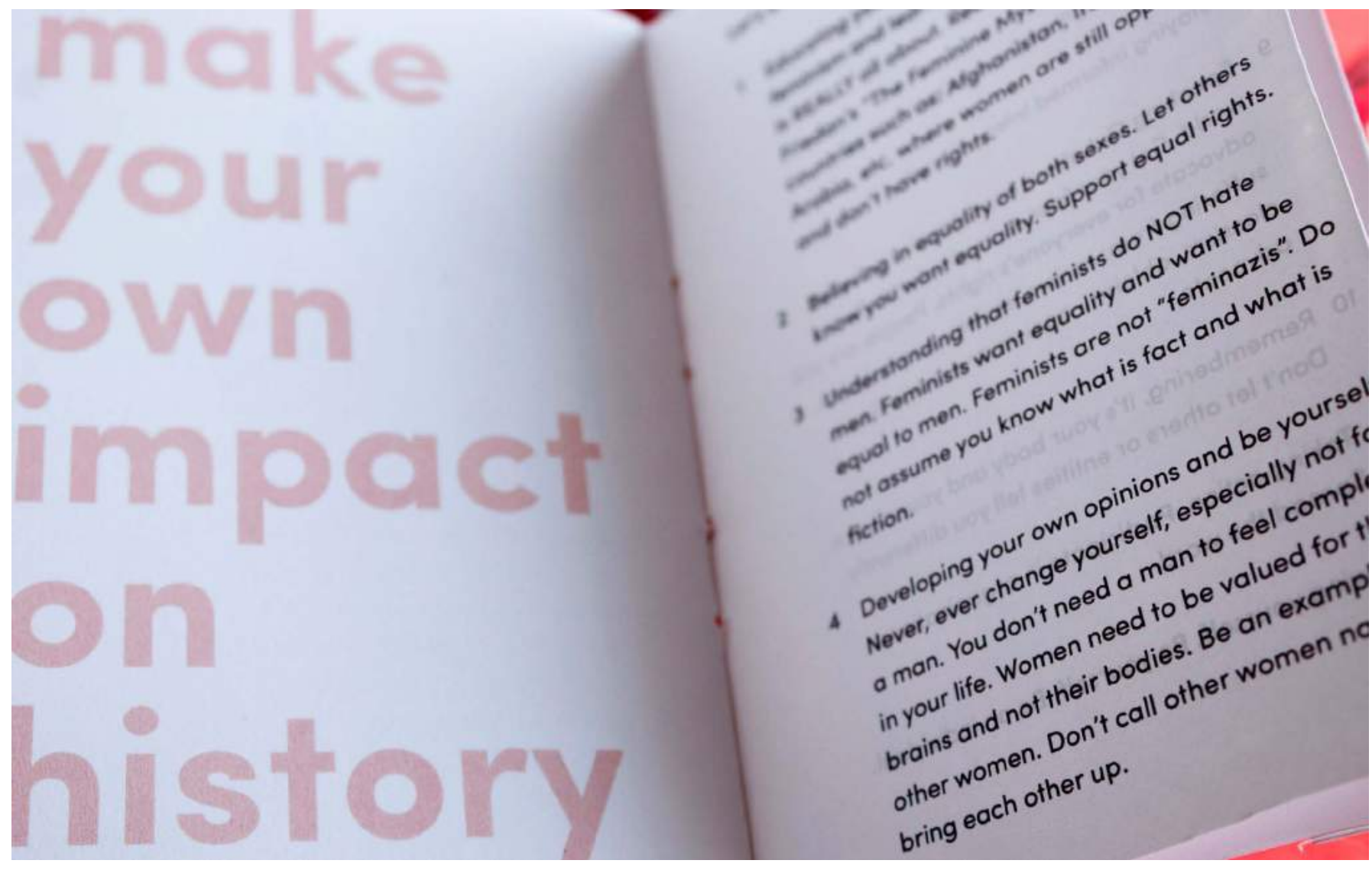

History Book Interior Spread 
Final Images

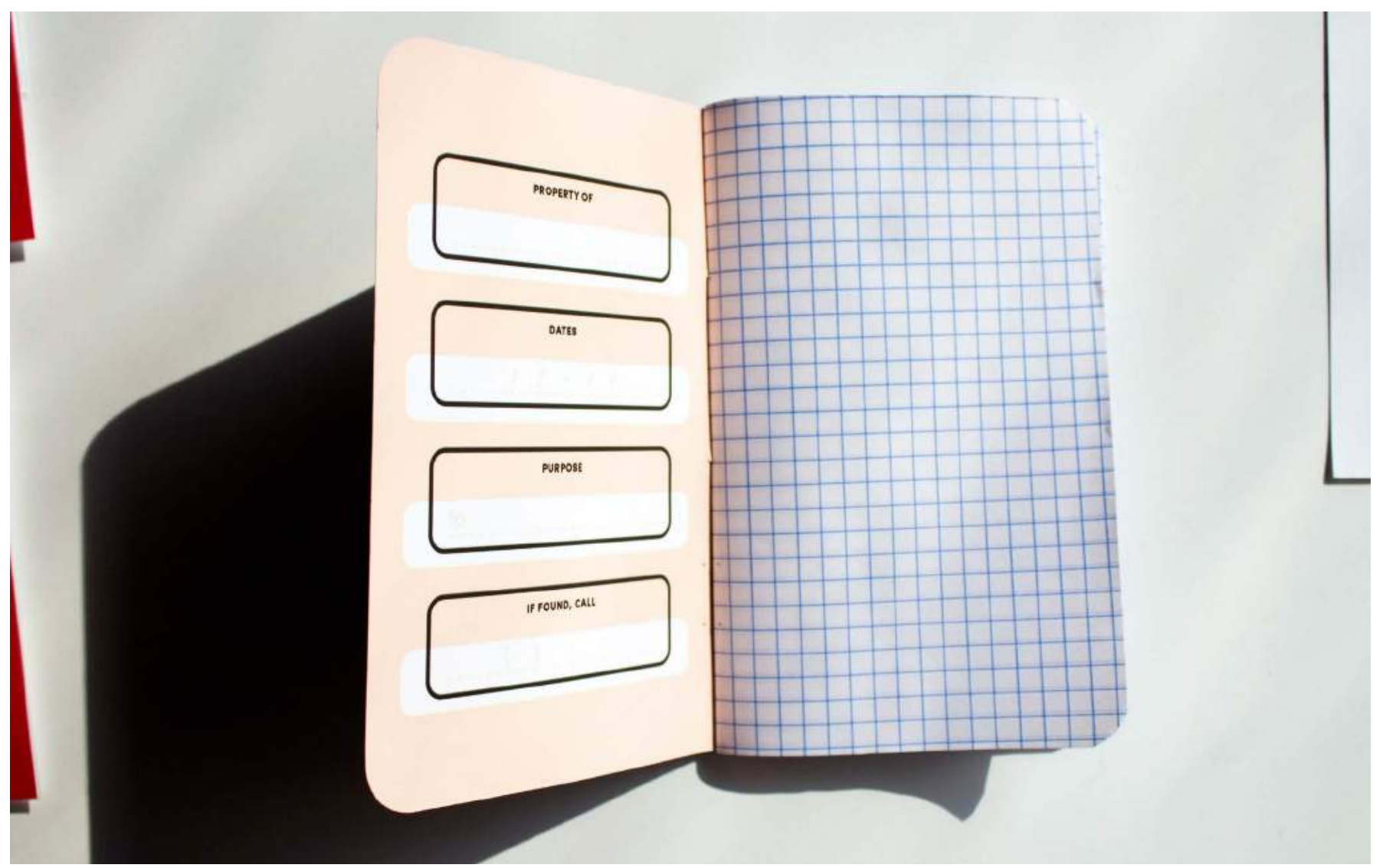

Notebook Front Interior 
Final Images

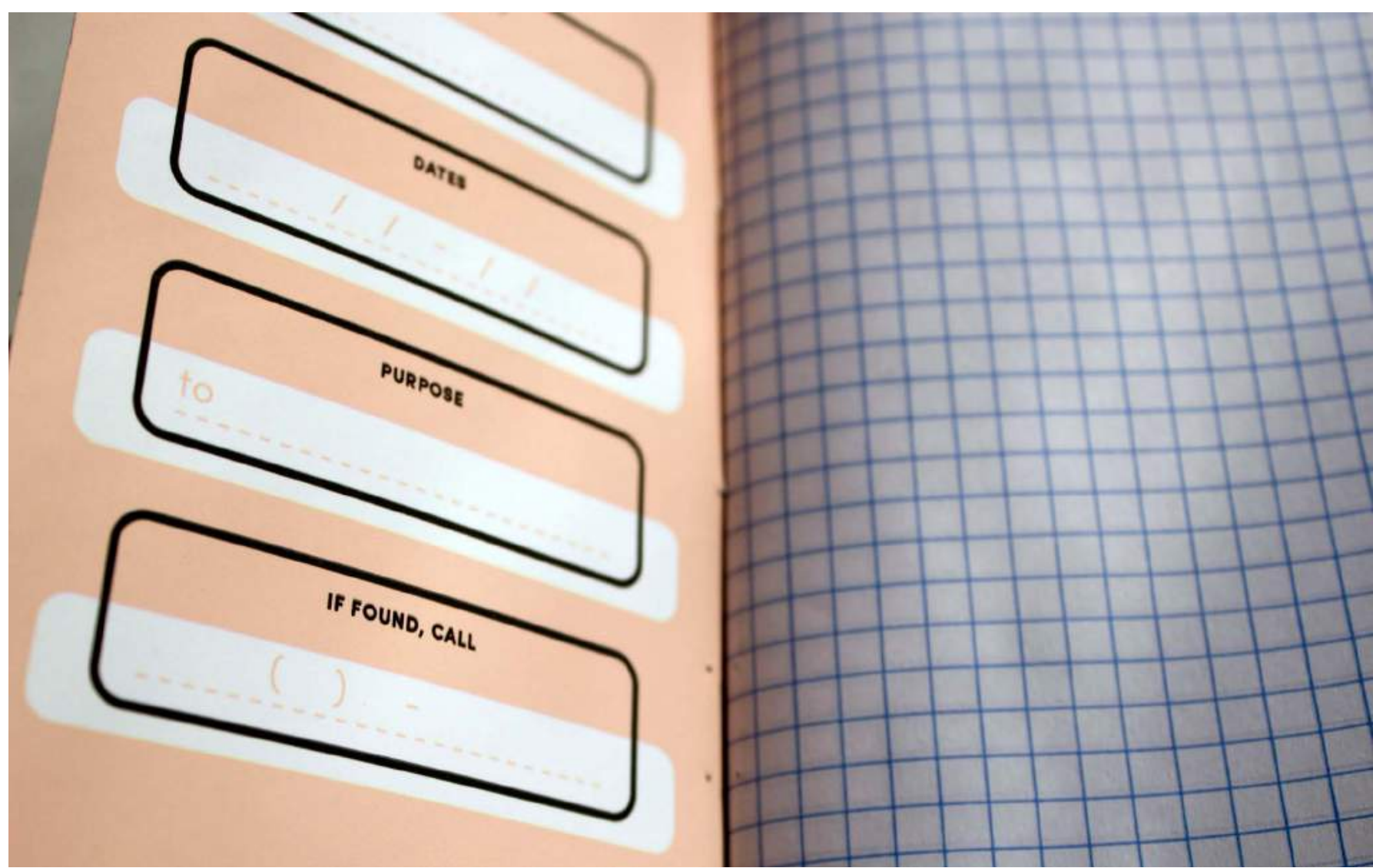

Notebook Interior Detail 
Final Images

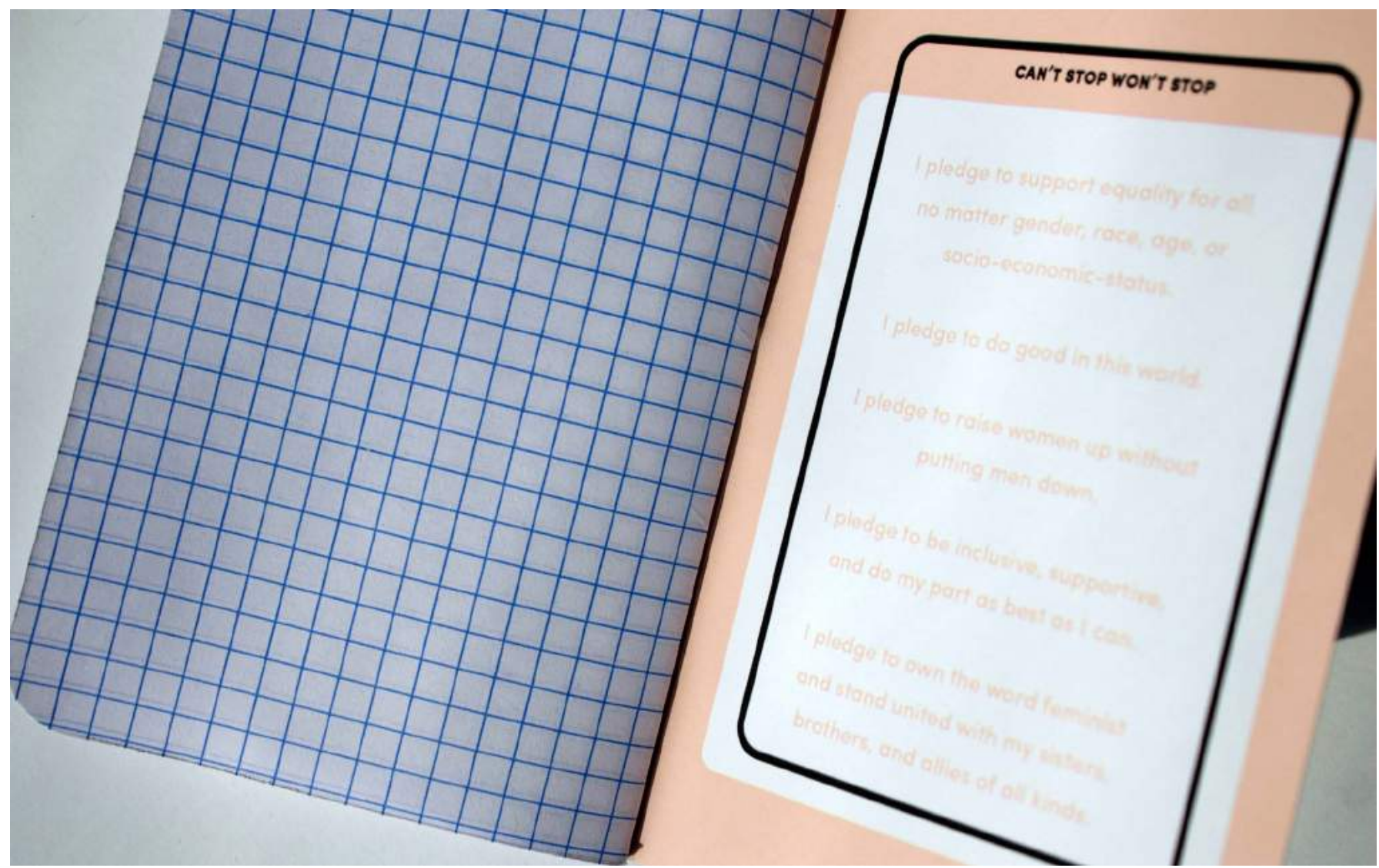

Notebook Interior Back Detail 
Final Images

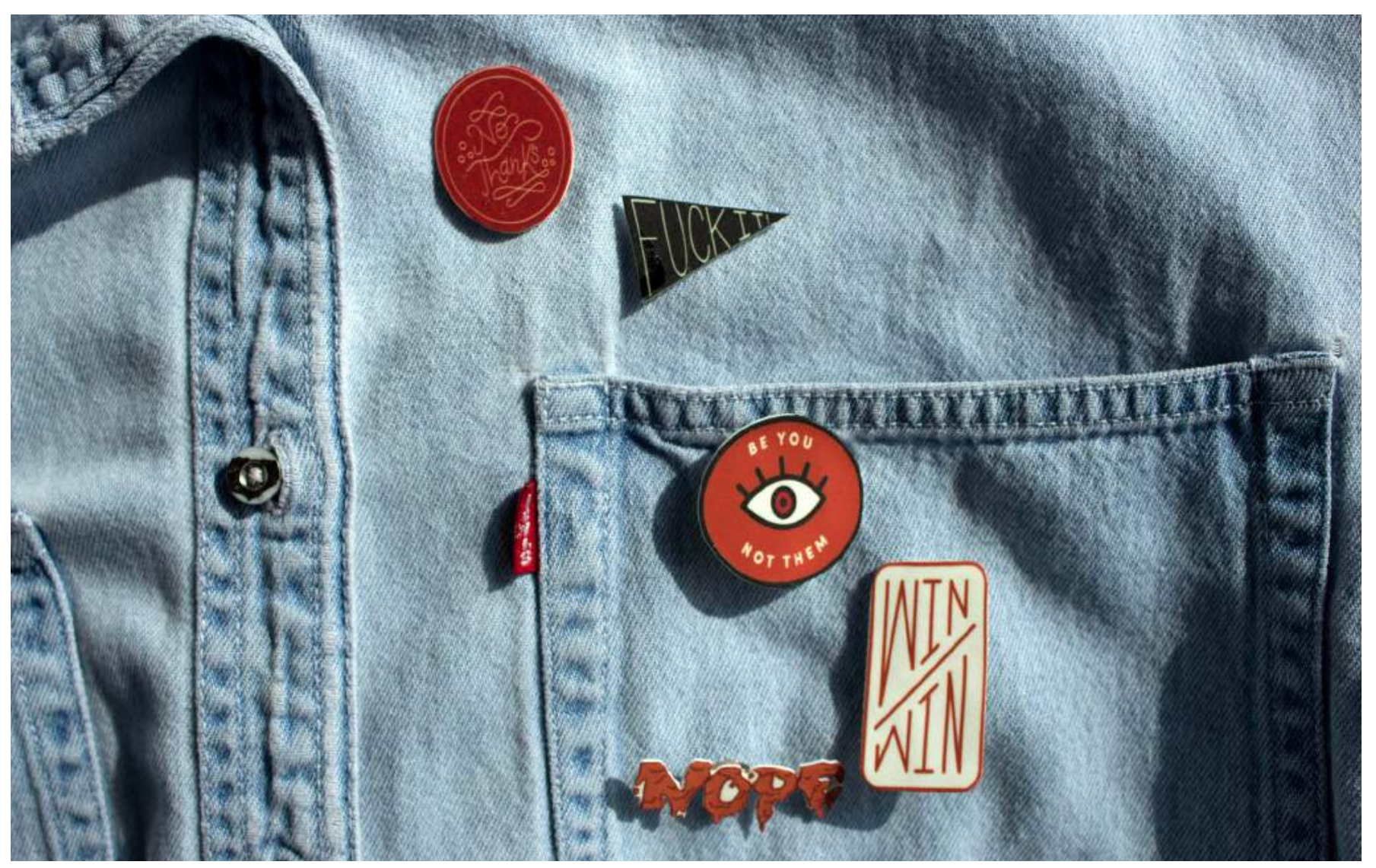

Pins in Context 


\section{Final Images}

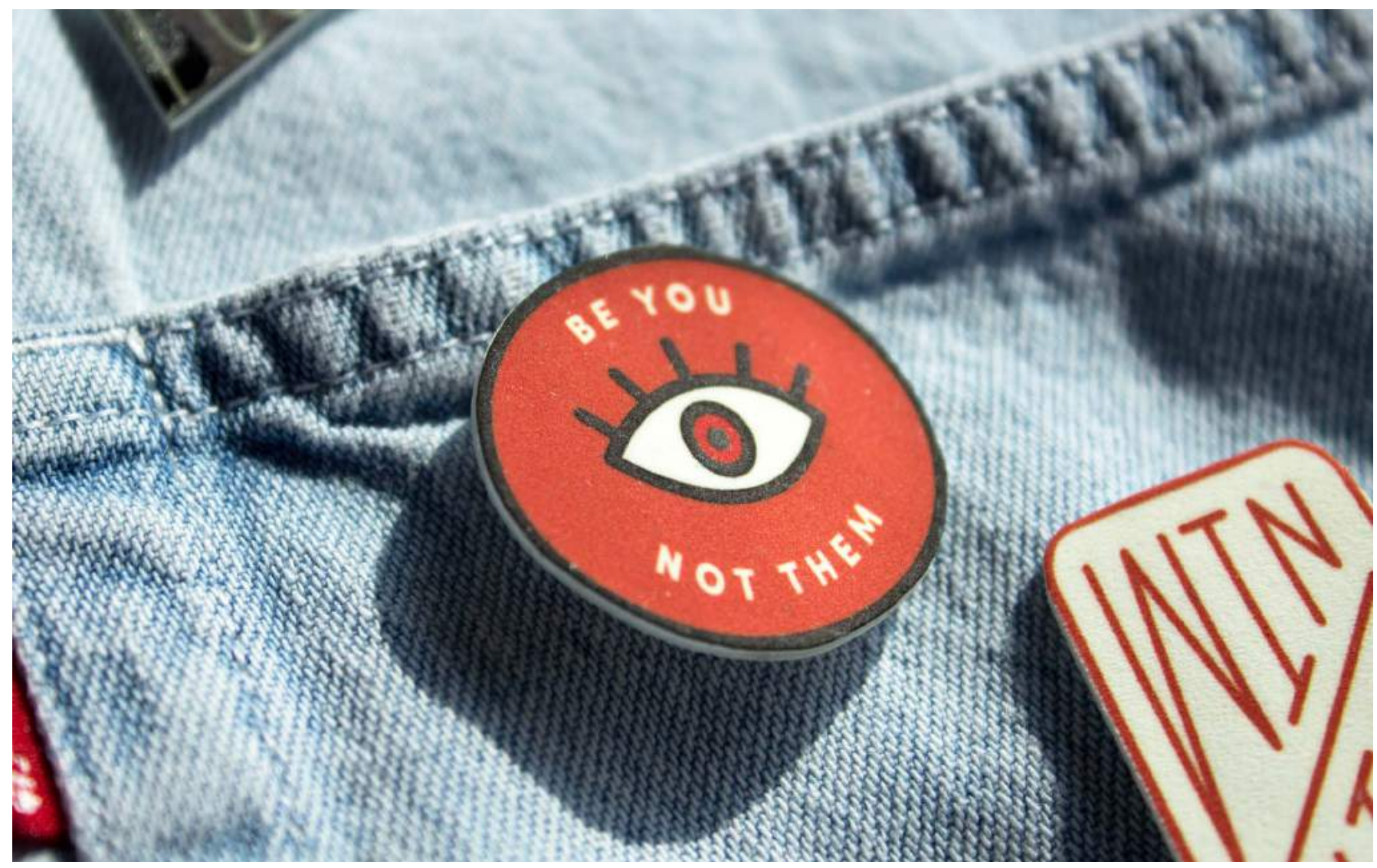

Be You Not Tehm Detail 
Final Images

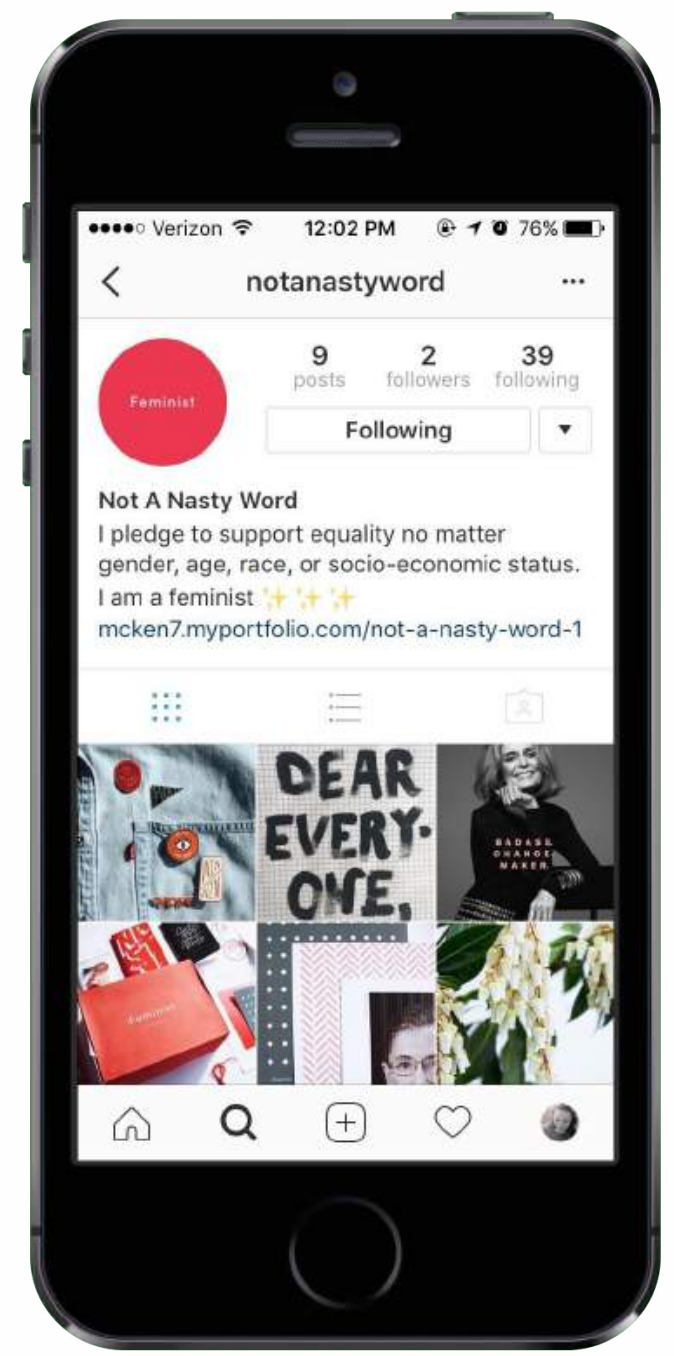




\section{Rationale}

I wanted to create a self-branding campaign that encourages young people to become self aware of the label of "feminist" and embrace its true intersectional definition, the striving for equality of all genders and people.

This branding experience was aimed at a primarily young audience of identifying females from ages 16 to 25 . Although aimed at these individuals, this branding kit is not exclusionary to other genders or age groups and doesn't use gender-specific language. I could see this kit thriving at a retailer such as Tender Loving Empire, Urban Outfitters, or Papersource.

This kit takes the shape of a box with external packaging. It includes 3 stickers, 5 pins, 5 patches, 4 art prints, a notebook, a history zine, a membership card, and a manifesto to hang in your space. These printed and tangible pieces are to be used to adorn one's life and space, be it dorm room, bag, denim jacket, work space, or grocery list. It also takes up space online with the hashtag \#NotANastyWord and the instagram account @notanastyword, where inspirational images are shared from feminist artists, photos of the products in action, and topical stories. With both of these platforms working together, the goal of this product is to encourage conversations in young people about feminism and its goals, as well as bringing feminism to individuals who would otherwise not identify. Success would be difficult to measure, but if this product did live in the real world success might be in monetary sales as well as a large and active viewership and following of the social media account.
My color palette is based on a bright red-orange. This color is passionate and fiery but also mutes down to different shades of peach that are nice tonally but aren't quite a girlish pink. This red strays from the feminist cliche of using pink everywhere, it also attempts to not alienate those who have a visceral reaction to the color pink being for girls. The other colors used are white for some cleanness and a dark grey which feels a little lighter and more textured than a dark black. The type used is Sofia Pro in the weight Black in all caps, it is rounded and kind of fun, but in the heavy weight is is punchy and present. It is accompanied by lighter weights of the typeface and in body copy it is used in varying capitals.

Moving forward I would like to explore making more products such as tarot cards, coloring books, and Virgin Mary Candles with other feminist icons, as well as looking into ways to expand this system beyond the box format. 


\section{Works Cited}

Armbrust, Armbrust \& Co, Www.armbrust.co, Jen. "Feminist." CARD-CARRYING

FEMINIST. N.p., n.d. Web. Oct. 2016.

Aronson, Pamela. "Feminists or 'Postfeminists'?: Young Women's Attitudes toward Feminism and Gender Relations." Gender and Society, vol. 17, no. 6, 2003, pp. 903-922. www.jstor.org/stable/3594676.

Buschman, Joan K., and Silvo Lenart. “I Am Not a Feminist, but...”: College Women, Feminism, and Negative Experiences.” Political Psychology, vol. 17, no. 1, 1996, pp. 5975. www.jstor.org/stable/3791943.

"Civilization - A Design Practice - Death Over Dinner." Civilization - A Design Practice. N.p., n.d. Web. Oct. 2016.

Guy Sheftall, Beverly. "Response from a 'Second Waver' to Kimberly Springer's 'Third Wave Black Feminism?"' Signs, vol. 27, no. 4, 2002, pp. 1091-1094. www.jstor.org/stable/ 10.1086/339632.

Harnois, Catherine E. "Different Paths to Different Feminisms? Bridging Multiracial Feminist Theory and Quantitative Sociological Gender Research." Gender and Society, vol. 19, no. 6, 2005, pp. 809-828. www.jstor.org/stable/27640852.Copy

Pettiway, K.Utilizing multiple design methods to resolve social problems (Order No. AAI1518557). Available from Sociological Abstracts. (1520341914; 201411274).

Retrieved from http://stats.lib.pdx.edu/proxy.php?url=http:// search.proquest.com.proxy.lib.pdx.edu/docview/1520341914?accountid=13265

Simic, Zora. “Door Bitches of Club Feminism’?: Academia and Feminist Competency.” Feminist Review, no. 95, 2010, pp. 75-91. www.jstor.org/stable/40928112.

WOMEN in ART. $(2016,10)$. Southwest Art, 46, 96-103. Retrieved from http://stats.lib.pdx. edu/proxy.php?url=http://search.proquest.com.proxy.lib.pdx.edu/docview/1822930273? accountid $=13265$

Zappaterra, Yolanda, et al. "Special Report: Graphic Activism." Grafik, no. 176, 2009., pp. 48-67http://stats.lib.pdx.edu/proxy.php?url=http://search.proquest.com.proxy.lib.pdx. edu/docview/1473832133?accountid=13265.

Zeiger, Mimi. “The New Design Activism.” Azure: Design Architecture \& Art, vol. 27, no. 210, 2011., pp. 90-95http://stats.lib.pdx.edu/proxy.php?url=http:// search.proquest.com.proxy.lib.pdx.edu/docview/1473729022?accountid=13265. 